\title{
Development Studies for a Novel Wet Oxidation Process Phase II
}

\section{Topical Report}

July 1994

Work Performed Under Contract No.: DE-AC21-92MC29107

U.S. Department of Energy Office of Environmental Management Office of Technology Development Washington, DC
For

U.S. Department of Energy

Office of Fossil Energy

Morgantown Energy Technology Center

Morgantown, West Virginia

By

Delphi Research, Inc.

Albuquerque, New Mexico 


\section{DISCLAMMER}

Portions of this document may be illegible in electronic image products. Images are produced from the best available original document. 


\section{DISCLAIMER}

This report was prepared as an account of work sponsored by an agency of the United States Government. Neither the United States Government nor any agency thereof, nor any of their employees, makes any warranty, express or implied, or assumes any legal liability or responsibility for the accuracy, completeness, or usefulness of any information, apparatus, product, or process disclosed, or represents that its use would not infringe privately owned rights. Reference herein to any specific commercial product, process, or service by trade name, trademark, manufacturer, or otherwise does not necessarily constitute or imply its endorsement, recommendation, or favoring by the United States Government or any agency thereof. The views and opinions of authors expressed herein do not necessarily state or reflect those of the United States Government or any agency thereof.

This report has been reproduced directly from the best available copy.

Available to DOE and DOE contractors from the Office of Scientific and Technical Information, 175 Oak Ridge Turnpike, Oak Ridge, TN 37831; prices available at (615) 576-8401.

Available to the public from the National Technical Information Service, U.S. Department of Commerce, 5285 Port Royal Road, Springfield, VA 22161; phone orders accepted at (703) 487-4650. 


\title{
Development Studies for a Novel Wet Oxidation Process \\ Phase II
}

Topical Report

Work Performed Under Contract No.: DE-AC21-92MC29107

U.S. Department of Energy

Office of Environmental Management

Office of Technology Development

1000 Independence Avenue

Washington, DC 20585
For

U.S. Department of Energy

Office of Fossil Energy

Morgantown Energy Technology Center P.O. Box 880

Morgantown, West Virginia 265070880

\author{
By \\ Delphi Research, Inc. \\ 701 Haines Avenue, NW. \\ Albuquerque, New Mexico 87102
}

July 1994 


\title{
Table of Contents
}

\begin{abstract}
Acknowledgments

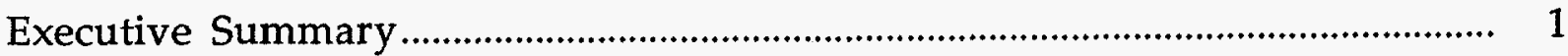

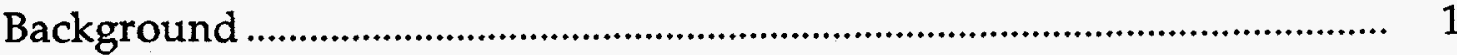

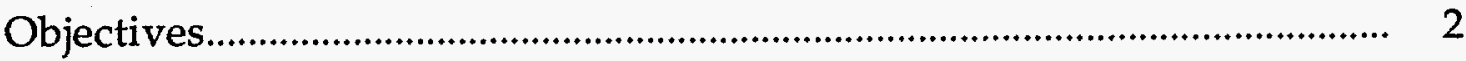

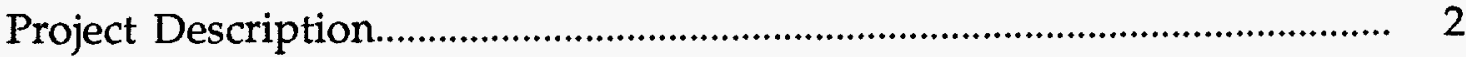

Phase II Task/Test Plan........................................................................................... 3

Results......................................................................................................
\end{abstract}

Task 1 - Site Selection.............................................................................

Task 2 - Stage 1 Engineering Design........................................................ 4

Conclusions and Recommendations .............................................................. 5

Section 1: Introduction ............................................................................................

$1.1 \quad$ Problem Statement.................................................................................. 7

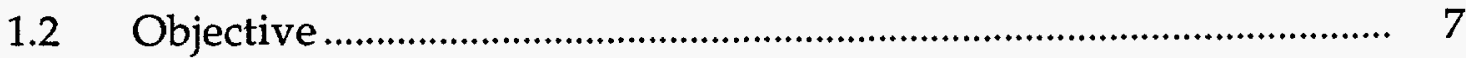

$1.3 \quad$ Process Description ............................................................................... 8

Section 2: Site Selection ............................................................................................ 10

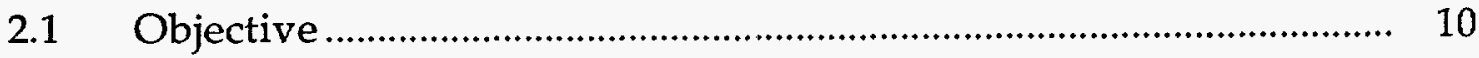

$2.2 \quad$ Procedure

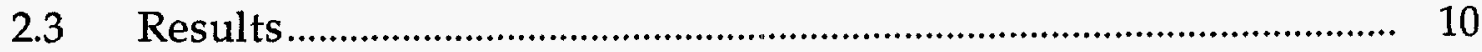

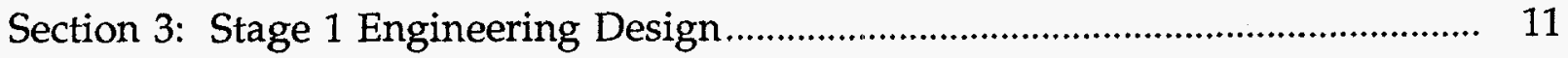

3.1 Objective .............................................................................................. 11 


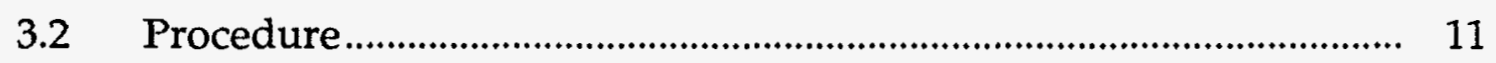

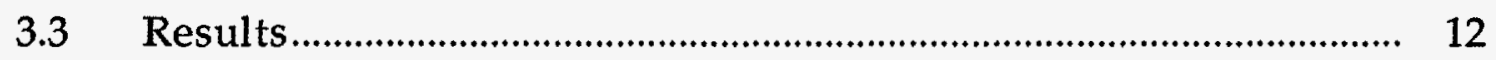

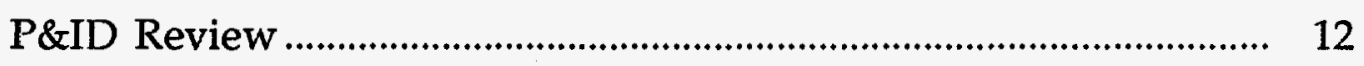

Preliminary Design Review ...................................................... 13

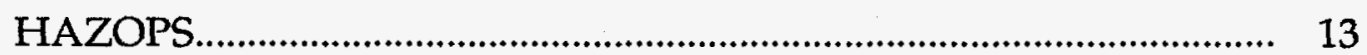

Critical Design Review .............................................................. 14 


\section{List of Figures}

Figure 1: The DETOXSM Process.................................................................................... 2

Figure 2: DETOXSM Process Schematic...................................................................... 6

Figure 3: The DETOXSM Chemistry.............................................................................. 9 


\section{Abstract}

DETOXSM is a catalyzed wet oxidation process which destroys organic materials in an acidic water solution of iron at 373. to 473 . K. The solution can be used repeatedly to destroy great amounts of organic materials. Since the process is conducted in a contained vessel, air emissions from the process can be well controlled. The solution is also capable of dissolving and concentrating many heavy and radioactive metals for eventual stabilization and disposal.

The Phase II effort for this project is site selection and engineering design for a DETOXSM demonstration unit.

Site selection was made using a set of site selection criteria and evaluation factors. A survey of mixed wastes at DOE sites was conducted using the Interim Mixed Waste Inventory Report. Sites with likely suitable waste types were identified. Site contacts, EM-30 (Waste Management) and EM-40 (Environmental Restoration) field representatives, and EM-50 (Office of Technology Development) Technical Program Officers and Managers at many sites, were contacted and asked for expressions of interest. Potential demonstration sites were ranked based on waste types, interest, regulatory needs, scheduling, ability to provide support, and available facilities. A site selection report with recommendations was prepared for review by DOE.

Engineering design for the demonstration unit is in progress and is being performed by Jacobs Applied Technology. The engineering design proceeded through preliminary process flow diagrams (PFDs), calculation of mass and energy balances for representative waste types, process and instrumentation diagrams (P\&IDs), preparation of component specifications, and a firm cost estimate for fabrication of the demonstration unit. After site selection, site representatives were invited to contribute to the design process. Regular design reviews were conducted during the effort.

Work still in progress includes a HAZOPS review, which will be conducted following establishment of a firm process and instrumentation diagram. Engineering design is also being reviewed by two independent consultants. Long lead time items will be identified after HAZOPS review, and a firm estimate made for demonstration unit fabrication cost. Critical design review will precede delivery of the Stage I design including final PFDs and P\&IDs, equipment specifications, equipment layout, and cost estimate. 


\section{Acknowledgments}

This development effort was conducted for the Morgantown Energy and Technology Center of the U.S. Department of Energy under Contract DE-AC2192MC29107. The DOE Project Officers were V. P. Kothari and J. Westhoff.

We would also like to acknowledge the guidance and assistance provided by Charles Brown (EG\&G Rocky Flats Plant), Dave Hixson (Jacobs Engineering Group, Inc., Weldon Spring Site), Galen (Butch) Freeman (Jacobs Engineering Group, Inc., Weldon Spring Site), Terri Uhlmeyer (Weldon Spring Site), Tom Pauling (DOE, Weldon Spring Site), Steve McCracken (DOE, Weldon Spring Site), Stanley Zygmunt (University of California, Los Alamos National Laboratory), Karen Azzaro (Westinghouse Savannah River Company), Steve Sheetz (Westinghouse Savannah River Company), Gene Lunn (Westinghouse Savannah River Company), John Corey (Westinghouse Savannah River Company), Jim Taylor (DOE Headquarters), John Patterson (DOE, Savannah River Operations Office), and Jan Berry (Oak Ridge National Laboratory). 


\section{Executive Summary}

\section{Background}

Great amounts of hazardous, toxic, and/or radioactive wastes have been generated at Department of Energy operational sites and in many areas of the private sector. These wastes may contain variable amounts of hazardous and/or toxic organic compounds, hazardous and/or toxic inorganic materials such as heavy metals, and radioactive elements.

The problem of waste which is both hazardous and/or toxic, and radioactive (often designated "mixed" waste) at Department of Energy sites is particularly acute, since there are few, if any, methods for its treatment and the Federal Facilities Compliance Act (FFCA) mandates the development of effective methods of dealing with mixed waste at government facilities.

The work reported herein has resulted from PRDA DE-RA21-92MC28245, Research and Development for Environmental Restoration and Waste Management Technologies, Sub-Research Area 3.05-Innovative Chemical and Biological Reactor Systems.

The technology proposed for development to meet the Department of Energy's needs was the DETOXSM process, a patented chemical treatment which oxidizes organic compounds to simple products. Figure 1 shows reactants and products in the process. Treatment is performed in an acidic water solution using oxygen gas as the oxidant.

Due to the novel combination of catalysts used in the solution, the process can oxidize most organic compounds at moderate pressure and temperature. The acidic water solution is capable of dissolving great amounts of many toxic and radioactive metals. Since treatment is performed in a water solution, the process is not especially sensitive to the water content of the waste. The process will also accept a large range of particle sizes and waste types, and is not especially sensitive to variations in waste content. 
Figure 1: The DETOXSM Process

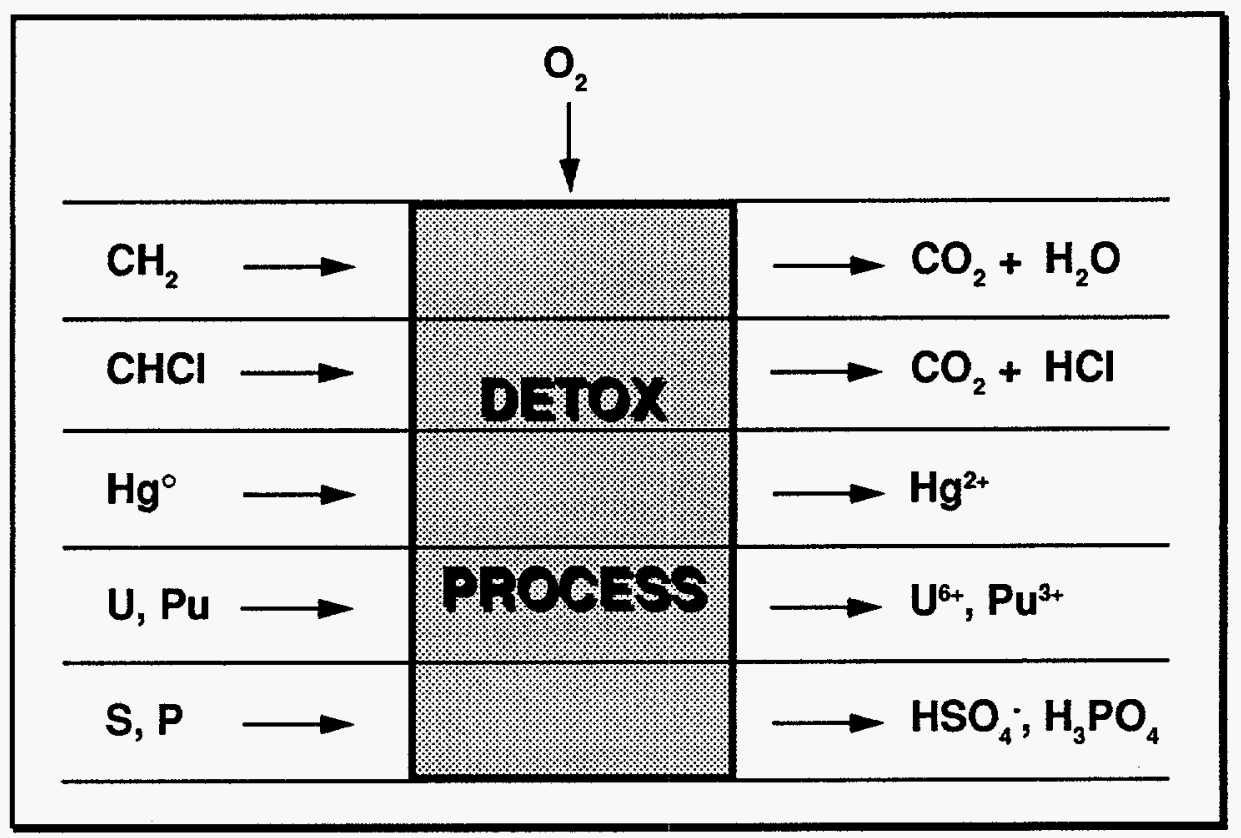

Although DETOXSM had shown promising results in testing on some organic and infectious waste types, the process had never been applied to complex hazardous and mixed wastes, which may contain a variety of organics and metals.

The Phase I effort of this project determined the practical range of application for the process in treatment of multicomponent wastes and performed a conceptual engineering study for the process in application to Department of Energy wastes.

In the Phase II effort reported here a survey of potential demonstration sites was conducted and engineering design performed for a demonstration unit.

\section{Objectives}

The objectives of the Phase II effort were to identify demonstration sites for DETOX $^{S M}$ and to perform the Stage 1 engineering design for a demonstration unit.

\section{Project Description}

Development of the DETOXSM process is planned to proceed in four phases. In Phase I, laboratory tests established the range of applications for the process and a conceptual design (Title I) was performed. In Phase II, a site selection survey has been conducted and the design of the demonstration unit completed through 
roughly Title II level (sufficient for costing, but not including detailed shop drawings). In Phase III, detailed design and construction of the prototype will be performed (Title III). In Phase IV, the demonstration unit will be operated in the field to evaluate its performance.

\section{Phase II Task/Test Plan}

Task 1 was performance of a demonstration site survey and preparation of a site selection report. A survey of mixed wastes at DOE sites was conducted using the Interim Mixed Waste Inventory Report. Sites with likely suitable waste types were identified. Facsimiled missives containing a description of the process, a description of the demonstration program, and a request for expressions of interest were sent to site contacts, EM-30 (Waste Management) and EM-40 (Environmental Restoration) field representatives, and EM-50 (Office of Technology Development) Technical Program Officers and Managers at many sites. Sites were then evaluated based on types of wastes available, interest in sponsoring a demonstration, ability to support a demonstration, regulatory requirements, site access, and facilities.

Task 2 was Stage 1 engineering design of the demonstration unit by Jacobs Applied Technology (JAT). Stage 1 design is roughly equivalent to Title II design. The unit was configured as a modular system. Design was begun using the conceptual design from the Phase I effort as a basis. Several representative waste types were identified which might be treated with the unit. Initial PFDs and P\&IDs were prepared and reviewed. Changes from the first review were incorporated and a second design review conducted to firm up the design. During the second review, representatives from the chosen demonstration sites were invited to participate in the design process. In addition, two independent engineering consultants are reviewing the design. At this point, equipment layout, equipment specifications, and long lead time items are being developed for the working design, fabrication time estimate, and fabrication cost estimate. A list of long lead time items and a cost estimate for fabrication will be submitted to Delphi Research, Inc. by JAT approximately six weeks prior to the Stage 1 design report to aid in project costing and schedule continuity. A final design report detailing the Stage 1 design will be prepared by JAT.

\section{Results}

\section{Task 1 - Site Selection}

The site selection survey of waste types identified ten sites which had potential waste streams for demonstration. Of the ten sites to which letters of introduction and technical information were sent, formal responses were obtained from EG\&G Rocky Flats Plant, DOE Weldon Spring Site, and Westinghouse Savannah River Corporation. Some questions about the process were received from EG\&G Idaho, Inc. 
Seven of the ten sites were felt to qualify based on telephone conversations with personnel at the sites and the waste types available. In addition to the sites above, Hanford Site, Fernald Site, and Los Alamos National Laboratory were included in the evaluation. Based on the seven evaluation factors, Savannah River Site and Weldon Spring Site were ranked as the best sites for demonstration. Weldon Spring Site has superior waste types, but Savannah River Site has better facilities. Rocky Flats Plant was ranked third due to lower rankings for support costs, regulatory requirements, site access, and site facilities. All of the other sites were lower ranked, primarily due to apparent low interest levels and resulting lack of communication. Based on these results, a two part demonstration at Savannah River Site and Weldon Spring Site was recommended. Added advantages of the "two-part" demonstration are:

1. The planned treatment of hazardous, non-mixed waste at Savannah River Site followed by relocation to Weldon Spring Site and the treatment of multiple types of mixed wastes. This approach will enable Delphi to obtain a history of organic destruction efficiencies and optimize operating conditions prior to introducing radioactive wastes into the system, thus any system modifications can be easily implemented prior to treating radioactive materials.

2. The treatment of non-radioactive materials will considerably enhance the decontamination issues associated with the transport of the unit to Weldon Spring Site.

\section{Task 2 - Stage 1 Engineering Design}

Stage 1 engineering design for a skid-mounted demonstration waste treatment unit is in progress as of this draft report. The unit will have a 1000 . L ( 250. gal) main reaction vessel of tantalum-lined titanium, and a tantalum process side condenser. The demonstration unit will be mounted on 3 modules. A vertical module approximately $8^{\prime} \times 12^{\prime} \times 30^{\prime}$ high will hold the reaction vessel/solids feed, water quench tank, and other equipment which will be exposed to radionuclides. A horizontal module approximately $8^{\prime} \times 10^{\prime} \times 25^{\prime}$ will hold equipment which should not be exposed to radionuclides. A third module approximately $8^{\prime} \times 14^{\prime} \times 20^{\prime}$ will hold the hot oil heating/cooling system; the hot oil module will need to be placed in a location external to a building to shed waste heat. The entire assembly is estimated to weigh approximately $80,000 \mathrm{lb}$. Long lead time items for the unit are primarily large components which will be fabricated from tantalum or Grade 7 titanium, i.e., the reaction vessel, product gas condenser, solution cooler, solids filter, and evaporator.

Design reviews to date have concentrated primarily on the solid waste feed system for the reaction vessel, solids removal from the reaction vessel, unit safety features, and the desired sensor and control elements. 
Solids feeding into a pressurized tank is a non-trivial problem, but is achievable using a combination of shredders, a slurry tank, and a progressive cavity pump.

Solids removal can be simplified by direct filtration of the process solution through a Nutsche-type, horizontal plate filter, with return of filtrate to the tank using a diaphragm pump.

Safety features on the unit are planned to include a video monitor on the solids feed, double walled tubing, redundant valves in critical areas, redundant sensors, redundant control hardware, leak detectors, cold water quench, an emergency blowdown tank, and lime/activated carbon beds for trace $\mathrm{HCl}$ and organic compounds removal.

Oxygen, carbon dioxide, hydrogen chloride, volatile organic compound, and radioactivity sensors will be used on the product gas outlet. In order to achieve the high quality data necessary for confirmation of emissions levels to EPA standards, a gas chromatograph/mass spectrometer is required to provide on-site analysis of organic compounds in gaseous and water emissions from the unit. Level sensors are required for the tanks. Flow, temperature, and pressure sensors will be installed as appropriate. The control system will be duplicate Programmable Logic Controller(PLCs) overseen by a PC system.

Figure 2 shows the process flow diagram for the demonstration unit. The unit will be operated in a continuous mode, with semicontinuous introduction of organic materials. Rate of organic material feed will be controlled by the amount of carbon dioxide in the product gases and the amount of organic which has been fed to the system. Oxygen addition rate will be controlled by the percentage of oxygen in the product gases.

\section{Conclusions and Recommendations}

Suitable sites for demonstration have been identified by Delphi Research, Inc. and approved by DOE. Stage 1 design is proceeding with no "show stoppers" encountered. It is recommended that Stage 2 design and fabrication be started as soon as practical, in particular arrangement for acquisition of long lead time items, to minimize schedule risk and carry forward the demonstration effort in good order. 
Figure 2: DETOXSM Process Schematic

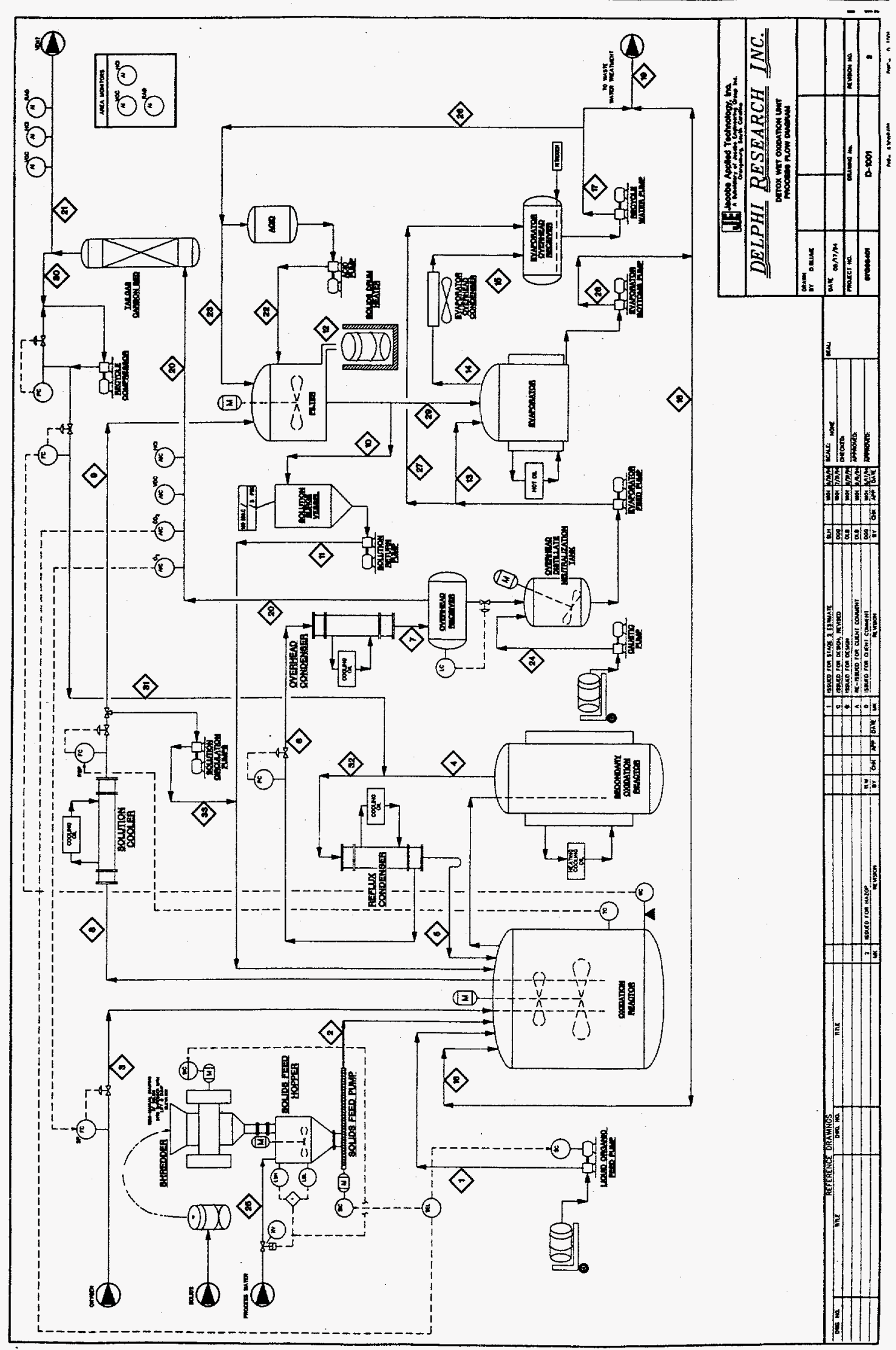




\section{Section 1}

\section{Introduction}

\subsection{Problem Statement}

Complex multicomponent hazardous and mixed wastes and remediates are a common problem at Department of Energy operational sites and in many areas of the private sector. These materials can contain variable amounts of hazardous and/or toxic organic compounds, hazardous and/or toxic inorganic materials such as heavy metals, and radioactive metals. The hazardous, toxic, and/or radioactive materials may be dispersed in other organic materials, sludges, soils, or water solutions.

The problem of mixed waste at Department of Energy sites is particularly acute, since there are few if any methods for its treatment and the Federal Facilities Compliance Act (FFCA) mandates the development of effective methods of dealing with mixed waste at government facilities.

What is needed is a robust, fairly omnivorous process for destroying a wide variety of organic waste components, while concentrating the inorganics and radioactive metals in a matrix for ultimate recovery and/or disposal. The process should use conventional technology to minimize development and application time, and it should minimize air and water emissions, operate safely, and be cost effective.

\subsection{Objective}

The objective of this Project is to develop a catalytic wet oxidation process (DETOXSM), which utilizes a concentrated, acidic solution of iron chloride and cocatalysts, for the treatment of multicomponent wastes and remediates. Successful development will provide a versatile treatment method which can destroy hazardous organics in a variety of matrices while simultaneously concentrating many metals in the process solution for recovery and/or disposal.

The Phase II effort described herein involved a survey of DOE facilities to identify suitable demonstration sites and Stage 1 (Title II) design of the demonstration unit. Additional efforts to apply the process to different waste streams are currently under way for the University of California, Los Alamos National Laboratory, and EG\&G Rocky Flats Plant (see Appendix A). 
Phase III of the Project will be Title III design and fabrication of a demonstration unit. Phase IV will be a demonstration of the process on nonhazardous, hazardous, and mixed organic wastes.

While the process may not provide stand-alone treatment of all applicable waste types, it holds promise of being able to provide significant volume reduction of mixed wastes and remediates, and conversion of mixed waste types to radioactive-only wastes. Some of the residues from the process would require additional treatment, such as immobilization, before ultimate disposal. Other residues, such as excess water and neutralized condensate brine from the process, should be non-hazardous, but under current law would require delisting before release.

\subsection{Process Description}

A patented process, DETOXSM is a combination of iron ions, a homogeneous oxidation cocatalyst (typically platinum and/or ruthenium ions), and an iron oxidation catalyst in an acid solution. Ferric iron in aqueous acidic solution oxidizes a wide range of organics to simple products (i.e., $\mathrm{CO}_{2}, \mathrm{H}_{2} \mathrm{O}, \mathrm{HCl}$ ) at temperatures of $373 .^{\circ} \mathrm{K}$ to $523^{\circ} \mathrm{K}$. Figure 3 illustrates the process.

The typical DETOXSM solution composition is about $60 . \%$ by weight ferric chloride and $4 . \%$ by weight $\mathrm{HCl}$ in water, with small amounts of dissolved platinum and ruthenium cocatalysts. Ferric iron is responsible for the oxidation of the organic compounds, and is reduced to ferrous iron in the reaction. The ferrous iron is reoxidized to the ferric state by reaction with oxygen. Thus, the iron ions act ultimately as a catalyst, being cycled between the ferric and ferrous states.

Extensive previous testing performed by Delphi Research, Inc. both privately and under contract to the U.S. Air Force, the New Mexico Research and Development Institute, and Los Alamos National Laboratory has established the ability of ferric iron to oxidize organic compounds, the effects of temperature on the reaction rate, and the advantages of using the cocatalysts. The details of previous research are too involved to present in this report, but may be found in various reports, technical papers, and patents (1-7). 
Figure 3: The DETOXSM Chemistry

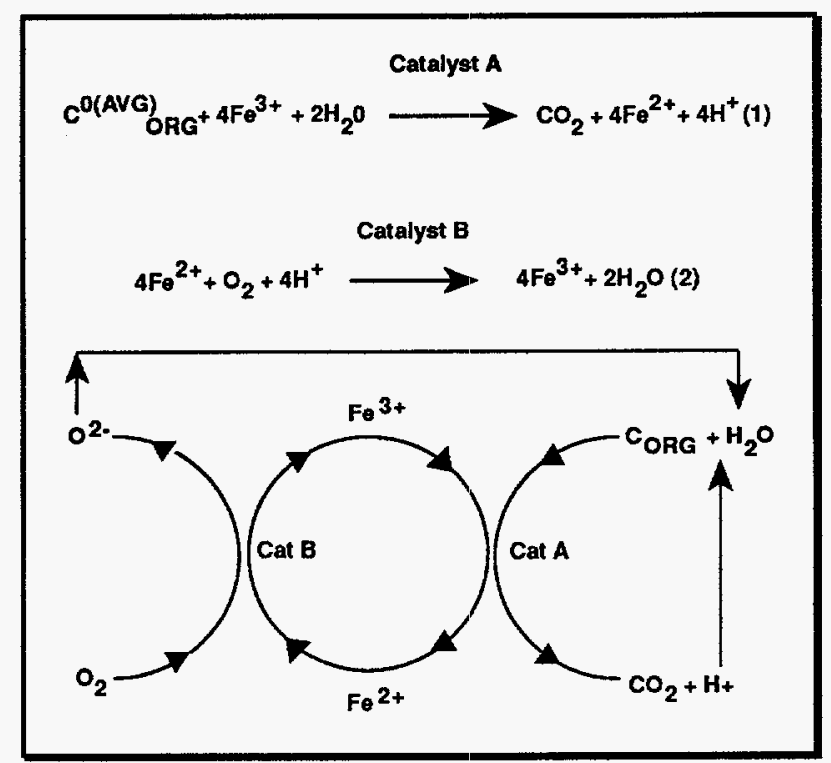




\section{Section 2}

\section{Site Selection}

\subsection{Objective}

Identification of suitable sites for demonstration of the technology was a primary goal of the Phase II effort. A desirable site would have a variety of wastes suitable for the process and characteristic of wastes throughout the DOE complex. It would also be able to support a demonstration effort, have suitable facilities available, have access for the demonstration unit, and have a good situation vis-avis the regulatory structure. The aim of this task was to prepare a site selection report with recommendations based on a survey and evaluation of DOE sites.

\subsection{Procedure}

The procedure used for survey and evaluation of sites has been given in the Site Selection Report, which is Appendix A to this document.

\subsection{Results}

The results of the site survey and evaluation have been given in the Site Selection Report, which is Appendix A to this document. The conclusion and recommendation was for a two part demonstration at Savannah River Site and Weldon Spring Site. 


\section{Section 3}

\section{Stage 1 Engineering Design}

\subsection{Objective}

Engineering design of a demonstration unit is required before a decision can be made to fabricate and test the unit. Design is also necessary to obtain an accurate cost estimate for fabrication of the unit.

The goal of this Task was, therefore, to perform a Stage 1 design (equivalent to Title II design) for the proposed demonstration unit. The Stage 1 design would include all engineering development necessary to accurately cost the unit, identify long lead time items, identify component specifications, and identify equipment layout. The design would not include shop drawings.

\subsection{Procedure}

Jacobs Applied Technology (JAT) was subcontracted to perform the Stage 1 engineering design. Appendix B to this document gives the Statement of Work which was given to JAT for the design effort. Appendix $C$ to this document gives the Stage 1 design schedule.

Stage 1 design was begun using as a basis the preconceptual design prepared in Phase I of the Project. A design kick off meeting was held to familiarize the parties with the specifics of the design process and to establish dates for review meetings.

Preliminary PFDs and P\&IDs were prepared and reviewed during June. Based on the site selection review process, several waste types were specified by Delphi Research for mass and energy balance calculations.

After site selection in late June, a second set of P\&ID's, along with calculated mass and energy balances, were prepared and reviewed in early July. At the second review, representatives from the chosen demonstration sites were invited to contribute to the design effort. The results of the second review were used to prepare firm P\&IDs.

A HAZOPS review was conducted on the system design in early August; a HAZOPS is equivalent to a Process Hazards Review. Changes from the HAZOPS review were incorporated in design before preparation of equipment specifications, equipment layout, long lead time items, and a fabrication cost estimate. 
A critical design review incorporating all of the desired changes was then conducted in late August to finalize the Stage 1 design. The Stage 1 design report was then prepared.

\subsection{Results}

Stage 1 engineering design was completed on schedule and on cost.

\section{PEID Review}

During review of P\&IDs, several issues were clarified. One of the most important of these issues was specifying design parameters for the solids feed system, including a shredder, stirred slurrying vessel, and progressive cavity pump. Another important issue was the solids filtration system, which was simplified to a closed, Nutsche-type filter, filtrate collection tank, and filtrate return pump. Many of the issues addressed in the P\&ID review were related to safe and reliable operation of the unit.

It was determined that size reduction for the solids feed could be accomplished with a shredder, and various types of potential solid feeds were specified. A cooler on the solids inlet to the reaction vessel was felt to be necessary to prevent excessive heating of the solids (in particular, softening of plastics) before their introduction into the reaction vessel. A video camera on the shredder compartment would allow monitoring of the size reduction operation, and a vent hood over the drum station and shredder would capture any vapors and/or dusts generated during container handling and shredding.

After much consideration, combined with the results of earlier filtration tests, it was determined that a closed, Nutsche-type filter could be used to filter solids from the process solution without need for a preconcentration device such as a hydrocyclone. Elimination of the hydrocyclone greatly simplified the design of this part of the unit, with resulting potential increases in reliability and safety. The filtered solution could be collected in a tank and pumped back to the reaction vessel; the pump would have to be seamless and very reliable. It was determined that hot oil should be used to cool the process solution before filtration, since the oil is a closed system which can be monitored for any leaks in the primary process solution containment.

A cold water quench for the reaction vessel was added to system design to serve as an emergency shut down device. A blow down tank was also added to the design to handle all process vents before they are delivered to a carbon bed; a similar arrangement was considered for the emergency vents. 


\section{Preliminary Design Review}

At preliminary design review, the changes incorporated in the P\&IDs, plus the heat and material balances, were reviewed for completeness to firm up the design before HAZOPS review. Representatives from the chosen demonstration sites, Savannah River Site and Weldon Spring Site, attended and provided input on their design requirements. No major changes in design resulted from the preliminary design review.

Preliminary design was guided by 29 CFR 1910, 40 CFR 264, and 40 CFR 265. In cooperation with chosen site representatives other potential design requirement documents were identified. The primary design requirement document was specified to be DOE Order 6430.1A, General Design Criteria. DOE-6430.1A was reviewed for relevant sections and these sections were reviewed as to appropriateness for demonstration unit design. Any relevant design criteria from DOE-6430 which it was desired not to follow were identified to the sites for review. A preliminary determination was made that the unit was a radiological facility for the purposes of Safety Analysis Review (SAR).

Note: From this point is described work yet to be completed as of the date of this draft report.

The results of the preliminary design review will be used by JAT to develop a more accurate cost estimate for fabrication of the demonstration unit and a list of long lead time items which needed to be placed on order as soon as possible in the fabrication process.

\section{HAZOPS}

The HAZOPS review will identify several areas of concern which need to be addressed, and result in some design changes.

Potential hazard sources specified for HAZOPS will include the following:

1. Hot, pressurized dilute acid/oxidant containing hazardous organic compounds, toxic metals, and radioactive metals in the reaction vessel and solids filtration system.

2. Hot, pressurized acid gas containing hazardous organic compounds in the reaction vessel and product gas outlet lines.

3. Flammable solid and/or liquid organic materials containing hazardous organic compounds, toxic metals, and/or radionuclides in the feed systems. 
4. Acidic solids rinses containing small amounts of hazardous organic compounds, toxic metals, and radioactive metals in the filtration system, evaporator tank, and return line.

5. Acidic condensed water containing small amounts of hazardous organic compounds in the condensate catch tank, evaporator tank, and return line.

6. Pure oxygen in the oxygen feed line.

7. Hot oil (in the cooling system).

8. Up to $440 \mathrm{VAC}$ electricity.

The HAZOPS process, as described in DOE Standard 1027, will be conducted on the design by analyzing each page of drawings for points of hazard, estimating probability of occurrence and severity of the event, and determining the actions to be taken (if any) to mitigate either occurrence or severity. The results of the HAZOPS review will be documented in the Stage 1 design report from JAT, which has previously been submitted as a separate deliverable.

\section{Critical Design Review}

Critical design review will bring together all of the parties in the demonstration process, i.e., Delphi Research, Inc., JAT, DOE-METC, and representatives of Savannah River Site and Weldon Spring Site, along with independent engineering consultants, to perform a final review of the Stage 1 design.

The complete design, equipment layout, materials of construction, sensors, control system and interlocks, design codes, containment features, and safety features will be reviewed for appropriateness in the demonstration effort. The results of the critical design review will be documented in this report and in the Stage 1 design report from JAT, Appendix B to this document. 
Appendix A

$-15-$ 
$-16-$ 


\title{
SITE SELECTION REPORT
}

FOR THE DEMONSTRATION OF THE DELPHI RESEARCH, INC. DETOXSM WET-OXIDATION WASTE TREATMENT SYSTEM

\author{
U.S. DEPARTMENT OF ENERGY \\ MORGANTOWN ENERGY TECHNOLOGY CENTER \\ Contract No. DE-AC21-92MC29107
}

Delphi Research, Inc.

May 27, 1994 
$-18-$ 


\section{Table of Contents}

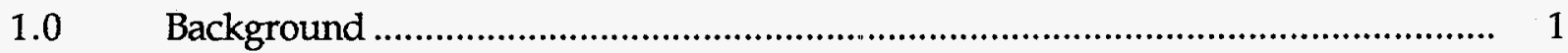

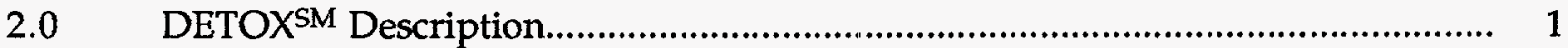

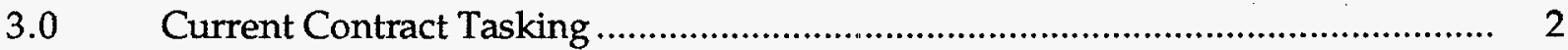

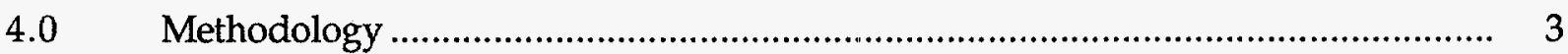

5.0 Identification and Evaluation of Candidate Sites..............................................

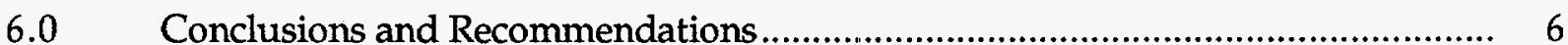




\section{List of Attachments}

Attachment 1 - Statement of Work Tasking 2.1, 2.2

Attachment 2 - Delphi Research Letter of Introduction

Attachment 3 - Site Response Letters

Attachment 4 - Site Contacts

Attachment 5 - Demonstration Site Identification Criteria (DOE Draft)

Attachment 6-Delphi Research, Inc. Site Selection Criteria and Evaluation Factors

Attachment 7 - Prioritized Waste Characterization Data

Attachment 8-Delphi Research, Inc. Risk Management Policy 


\subsection{Background}

The Department of Energy (DOE) has numerous sites where mixed and hazardous wastes are stored, produced, or still uncontained. Landfilling, incineration and long-term storage techniques have been the traditional means of disposing these wastes. However, new regulatory restrictions either prevent such disposal techniques or make the use of such methods costly. The DOE has therefore initiated an effort to develop and demonstrate new disposal technologies which have direct application to existing sites. One of the Mixed-Waste Integrated Program goals is to develop waste treatment technologies which safely dispose of hazardous organics.

In September, 1992, Delphi Research, Inc. (DRI) was awarded a Program Research and Development Agreement (PRDA) contract with the Department of Energy, Morgantown Energy Technology Center (DOE-METC). The purpose of the Phase I of this PRDA contract was to conduct laboratory tests to determine if a DRI patented wet-oxidation waste treatment process, DETOX $^{\mathrm{SM}}$, has the potential to effectively treat several organic wastes.

Phase I was completed in February, 1994, with Rocky Flats and Weldon Spring being recommended as the demonstration site(s). DOE was not ready to make a final site decision at that time and the site selection process was deferred until Phase II.

\subsection{DETOX ${ }^{S M}$ Description}

The DRI patented, catalyzed wet-oxidation technology destroys the organics in wastes while containing and concentrating inorganics (including radionuclide metals) for recovery or disposal. The process has potential application to a wide variety of wastes and sites.

DETOXSM utilizes a patented combination of iron ions, a homogeneous oxidation cocatalyst, and a ferrous iron-to-ferric iron oxidation catalyst in an acid solution to oxidize organic compounds. Potential applications include the treatment of used lubricating oils, cleaning and recycling of alkane solvents, and destruction of hazardous waste components.

The DETOXSM process is a unique and valuable means of oxidizing a variety of organic and inorganic materials. Figure 1 shows examples of process reactants and products. Treatment is performed in an acidic water solution using oxygen gas as the oxidant. Due to the novel combination of catalysts used in the solution, the process can oxidize most organic compounds at moderate pressure and temperature. The DETOXSM solution is capable of dissolving great amounts of many toxic and radioactive materials. 
Figure 1: $\quad$ The DETOX ${ }^{S M P r o c e s s}$

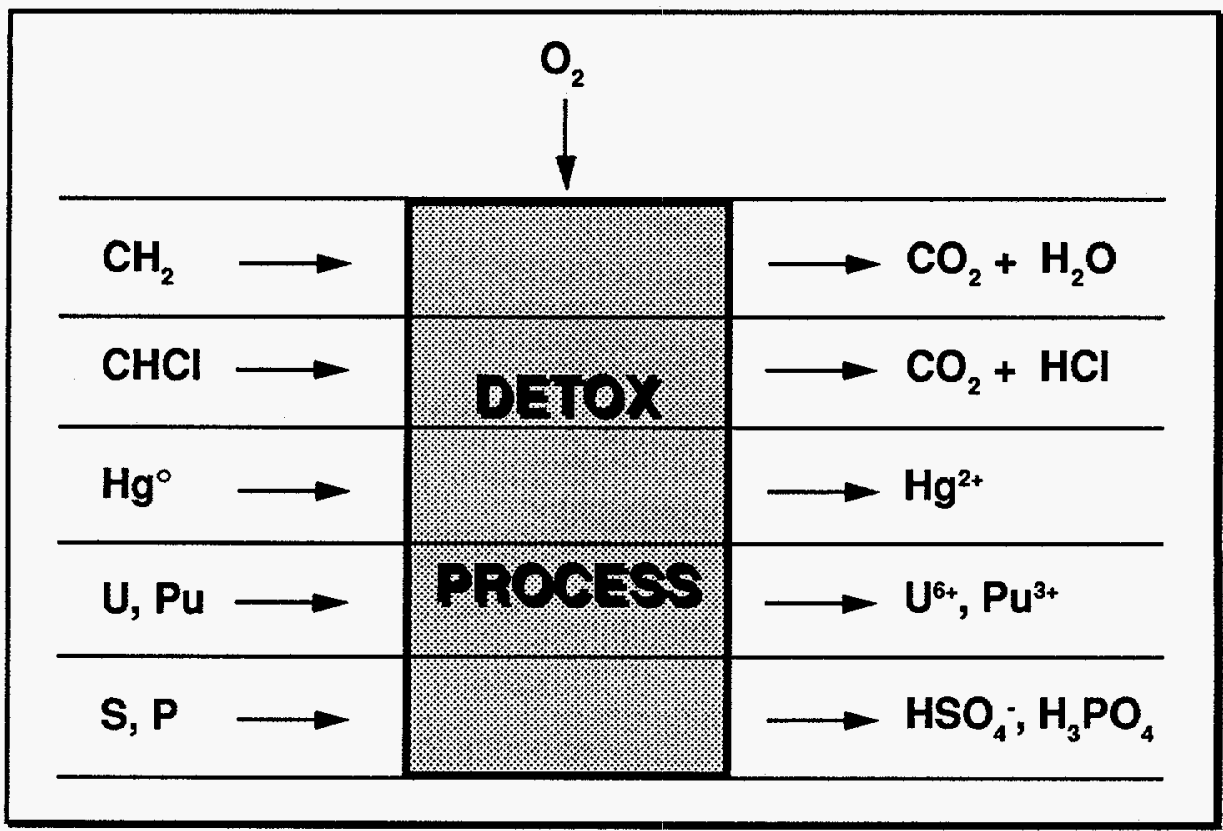

This reaction involves the use of iron and a cocatalyst to oxidize organic compounds to carbon dioxide. Heavy metals are retained in the DETOXSM solution and may be removed by precipitation or other suitable methods. Other inorganics and salts can be removed by precipitation. Excess water is removed by evaporation. As the iron is catalytically cycled between iron(III) and iron(II), the DETOXSM solution is not expended.

Organic materials oxidized in development studies include cellulose, woody wastes, aromatic hydrocarbons, chlorinated hydrocarbons (including PCBs), mineral oils, and terpene solvents. Extensive chemical analysis has been conducted on the reaction product gases, demonstrating the lack of nitrogen oxides or sulfur oxides.

Hazardous organics are broken down and the carbon oxidized to carbon dioxide. Any heavy and/or radioactive metals released in the destruction process are concentrated in the process solution or precipitated. Because capital and operating costs are relatively low, this process can offer an inexpensive method for volume reduction of many wastes.

\subsection{Current Contract Tasking}

Phase II of the DOE-METC contract with Delphi Research was awarded on March 29, 1994, and includes two primary tasks: (1.) Demonstration Site Selection support, Task 2.1; and (2.) Engineering Design of Prototype Unit, Task 2.2. This "Site Selection Report" is the product which addresses the Delphi Research requirement to assist DOE in identifying and evaluating alternative sites for the demonstration of the prototype DETOXSM waste treatment unit. See tasking paragraphs from the DOE-METC Statement of Work (SOW), Attachment 1. 
This report contains the information which DRI has been able to collect from the various DOE sites since March 29, 1994. A prioritized list of recommended demonstration sites have been developed based on several site evaluation factors. The final decision on demonstration site(s) will be made by DOE using this report and other factors.

Site waste characterization data for three sites-Rocky Flats, Los Alamos, and Weldon Spring-were well understood by DRI before the start of Phase II. Delphi Research has contracts with Rocky Flats and Los Alamos to determine the effectiveness and suitability of the DETOX $^{\text {SM }}$ process in treating selected wastes at these sites. Weldon Spring was one of the candidate sites which DRI surveyed during the last phase of this METC contract. The initial contacts, early in this Phase II, with several other DOE sites resulted in little feedback from our letters of introduction and requests for preliminary interest in hosting the proposed demonstration. This will be discussed further in the next section on Methodology.

Purpose The purpose of this report is to provide assistance to DOE-METC to: (a.) determine the site(s) level of interest in hosting this demonstration; (b.) obtain waste treatment requirements; (c.) gather waste characterization data; and (d.) identify site-specific installation and operation requirements. Most of the issues/data requirements are addressed in this report. However, some sites have been slow in providing their level of interest in hosting a demonstration.

Objective The project objective for the demonstration is technical success of the prototype demonstration. There are several factors and considerations which define "technical success" and these will be discussed in the Site Evaluation section.

\subsection{Methodology}

Delphi Research used a two step process in developing the recommendations for a Phase IV demonstration sites. Step one was an effort to assess whether a site is qualified as a demonstration site. Delphi is applying prudent risk management practices in planning the prototype demonstration. Even though the DETOXSM technology has the potential to treat a wide variety of mixed and hazardous waste types, the demonstration should initially treat wastes which closely approximate materials which have been treated in the Delphi Research laboratory in Albuquerque. In this context, waste compatibility/suitability is the top criteria in deciding if a site is a qualified DETOXSM demonstration location. Approximately forty (40) letters were sent to ten sites, DOE Headquarters, and other field activities in early April, 1994. These letters introduced the DETOXSM technology and asked for site interest in hosting a demonstration. A sample Delphi letter of introduction with the distribution list is included in Attachment 2.

Step two in our site recommendation process was to identify evaluation factors which are most important to the success of the demonstration. Note that some of the criteria for site identification are the same or very similar to the evaluation factors. Since step one, site qualification, is independent from the evaluation process, sites are not in double jeopardy. The evaluation of the seven qualified candidate demonstration sites is summarized in Table 1.

There were a few telephone calls from the sites in response to these letters. One site (INEL) wrote a letter asking some process questions in response to our information package. Rocky Flats, Weldon Spring Site, and Savannah River Site were the only sites to respond with written 
confirmation of interest in hosting the demonstration and providing additional new site information. See site response letters, Attachment 3.

When it became apparent that some sites were either not interested or could not respond on our time table, DRI spent many hours attempting to make telephone contacts with the sites. Attachment 4 is our current list of site contacts at the seven sites with compatible wastes.

In the telephone follow-up, SRS, WSS, INEL and Fernald have shown a high level of interest in a DETOX ${ }^{S M}$ demonstration at their site. Savannah River and Weldon Spring are two sites which have been visited in this contract phase regarding a DETOX ${ }^{S M}$ demonstration. Other sites remain under consideration as a demonstration location. At the request of WSS, we visited their site to further define demonstration requirements and address compliance issues with state regulators.

\subsection{Identification and Evaluation of Candidate Sites}

Site Identification and Qualification. Attachment 5 provides draft DOE-METC guidance on demonstration site identification. These criteria were used to develop a consolidated list of three criteria which DRI used in identifying candidate sites. Attachment 6 offers more discussion on the three Delphi Research identification criteria, but in summary, a site to qualify as a DETOXSM demonstration location must: (1) have wastes suitable/compatible for the DETOXSM process; (2) permit Delphi Research and the unit fabrication and engineering support contractor personnel access to the site; and (3) provide or facilitate site-specific support.

Site Evaluation. The evaluation factors which we have used in Table 1 were selected to help ensure a successful technology demonstration. Attachment 7 contains a prioritized list of wastes by site.

Factor 1 - Site interest in hosting the demonstration. Although the factors are not weighted, the interest and cooperation by demonstration site personnel will have a significant impact on our site recommendations. This factor may be the single best indicator of how the site will integrate the prototype unit into their schedule, provide site support, and generally, do everything possible to achieve demonstration success. And for these reasons, there is a measure of multiple jeopardy in Table 1. Also, sites which did not provide sufficient data or feedback for a thorough evaluation have been assigned an average rating for most factors.

Factor 2 - Site regulatory requirements. There is no site with known regulatory requirements which preclude a DETOXSM demonstration. However, in some instances treatment of Toxic Substances Control Act materials may require application for a full permit.

Factor 3 -Scheduling. Since the Phase IV demonstration schedule is not well defined, the rating for this factor is very sensitive to the spirit of cooperation which the sites have demonstrated in our surveys conducted to date.

Factor 4 - Cost to the project. There is no established DOE procedure for funding technology demonstration site support costs. Some sites have expressed willingness to absorb their support costs out of their operating budgets, others intend to ask for supplemental funding 
from DOE, and others have suggested that site support costs are legitimate charges to Delphi Research. Therefore, the costs for site support by DOE and M\&O personnel are secondary in assigning a rating for this factor. The costs and challenges for Delphi Research and Jacobs Engineering, the planned fabrication contractor, in supporting a prototype demonstration have a relatively large impact on the ratings for this factor.

Factor 5 - Site waste types are representative of other DOE sites. Meeting the intent of this factor helps ensure wide application of the DETOX ${ }^{S M}$ technology, assuming a successful demonstration and available and affordable waste treatment systems. Sites with the most compatible wastes with regards to the Delphi laboratory testing are given better ratings since starting with the most compatible wastes will reduce the demonstration risks. Also, sites whose wastes provide a gradual ramp up in waste complexity and difficulty are more desirable as an initial demonstration site.

Another issue that this factor includes is a preference to demonstrate the full capabilities of the DETOXSM waste treatment unit. The current design has provisions for both a solid and liquid waste feed subsystem; the site wastes should utilize both feed options in a complete demonstration. Other design features should be exercised in the course of a demonstration either at a single or multiple sites.

Factor 6 - Site access restrictions. Delphi Research developed and patented the chemical oxidation process upon which this technology is based. The system has never been operated by any other contractor and has never been used to process hot wastes. Delphi Research is the expert on the chemical process and has a lot at risk in this technology. In order to establish an expertise basis for commercialization, Delphi should be permitted to operate the prototype unit during the demonstration.

Some sites feel the need to restrict our access to the unit and unit operators during the demonstration. These sites have been given lower ratings. Delphi Research fully understands and appreciates the requirements and demands in working on a sensitive DOE site and treating mixed wastes. The Delphi Research Risk Management Policy, Attachment 8, further explains our concerns and interests regarding these issues.

Factor 7 - Demonstration site facilities. The facilities to house the demonstration unit, and other associated support facilities, were not included as an evaluation factor in the original Delphi list in Attachment 6. Site facilities became an important consideration based on site visits. The range in type and quality of site support facilities is too great to ignore. 
Table 1: Site Evaluation

\begin{tabular}{||l|c|c|c|c|c|c|c||}
\hline $\begin{array}{l}\text { Demonstration Sites } \\
\text { Evaluation Factors } \downarrow\end{array}$ & RF & SR & HAN & FER & INEL & WS & LANL \\
\hline 1. Interest & 3 & 3 & 2 & 2 & 2 & 3 & 1 \\
\hline 2. Regulatory Regts & 2 & 3 & 2 & 2 & 2 & 3 & 2 \\
\hline 3. Scheduling & 3 & 3 & 2 & 2 & 2 & 3 & 2 \\
\hline 4. Costs & 1 & 3 & 2 & 2 & 2 & 2 & 2 \\
\hline 5. Waste Types & 3 & 2 & 2 & 3 & 3 & 3 & 2 \\
\hline 6. Site Access & 2 & 3 & 2 & 2 & 2 & 3 & 1 \\
\hline 7. Site Facilities & 2 & 3 & 2 & 2 & 2 & 2 & 2 \\
\hline Total Points & 16 & $\mathbf{2 0}$ & $\mathbf{1 4}$ & $\mathbf{1 5}$ & $\mathbf{1 5}$ & $\mathbf{1 9}$ & $\mathbf{1 2}$ \\
\hline
\end{tabular}

Note: Evaluation Factor ratings are relative; 3 is a top rating, 2 an average rating, and 1 a low rating. Factors are equally weighted for this report.

Based on available information, Savannah River and Weldon Spring are clearly the best candidate sites.

\subsection{Conclusions and Recommendations}

Ten sites were considered as potential demonstration locations for the Delphi Research prototype DETOX ${ }^{\mathrm{MM}}$ waste treatment unit. Seven locations were determined to be qualified as suitable demonstration sites. Savannah River and Weldon Spring were evaluated as the best sites for technology demonstration. Because of growing interest, Hanford, INEL, and Fernald may be visited to conduct further review and assessment, and may become more viable demonstration sites. If these visits change the recommended demonstration sites, Delphi Research will issue a supplemental report.

Based on available information, Delphi Research recommends that both Savannah River and Weldon Spring continue as top priority demonstration sites. The Phase IV demonstration should be conducted at both sites or at a single site in a measured, build-up fashion. Unless there are long range budget planning or scheduling reasons to select a single site, Delphi Research recommends that the top two sites be used to influence the final design of the prototype DETOX ${ }^{\mathrm{SM}}$ unit. 
Attachment 1

$-27-$ 
$-28-$ 


\section{Tasking from Current DOE-METC SOW \\ Contract Number DE-AC21-92MC29107}

\section{Phase II - Prototype Design and Site Selection}

\section{Task 2.1-Demonstration Site Selection}

The contractor shall assist DOE for identification of additional potential field sites for initial testing and long-term demonstration of the DETOX ${ }^{\mathrm{MM}}$ process concept. This work shall include visiting additional interested sites and get information like waste treatment requirements, available waste characterization data, installation and operation requirements for each site. This information, along with the current information available (Rocky Flats site, Weldon Spring site, and Los Alamos site), shall be submitted to DOE COR within sixty (60) days after the Phase II award. The contractor shall also recommend the specific sites most suitable for the DETOXSM waste treatment technology. DOE shall review the site information and select one or more sites within thirty (30) days for the purpose of demonstrating the prototype unit.

\section{Task 2.2 - Engineering Design of Prototype Unit}

The contractor shall initiate engineering design efforts based on available data and incorporate relevant information from the site surveys Task 2.1 before the first major design review. The prototype unit shall be capable of treating multi-component low-level mixed and hazardous wastes. The prototype unit shall be designed for the modular construction on the skids for easy transportation to the field sites. The detailed engineering design shall include but not limited to the necessary drawings, equipment specifications, wiring diagram, instrumentation, monitoring controls, safety features, and the overall system configurations information sufficient for procurement of equipment, control instruments, fabrication, and assembly of the unit. 
$-30-$ 
Attachment 2

$-31-$ 
$-32-$ 
Delphi Research, Inc.

Letter of Introduction

with Distribution List

NOTE: Letters were tailored and personalized for each recipient. 
$-34-$ 
94-PMD-L050

April 7, 1994

Mr. James Taylor

U.S. Department of Energy

Office of Technology Development

Mail Stop: EM-55

Washington, DC 20585

Dear Mr. Taylor:

We have briefly communicated with you previously about the DETOX ${ }^{\mathrm{SM}}$ waste treatment process. The DETOX ${ }^{5 M}$ process can treat liquid and solid organic wastes, sludges, soils, debris, and other types of wastes. Development is proceeding apace, with very promising results. Demonstration at a practical scale is the next development goal.

Development of the DETOXSM process through DOE's Office of Technology Development and Morgantown Energy Technology Center is planned to proceed through four phases.

In Phase I, which is complete, laboratory tests have established the range of possible applications for the process and a conceptual engineering study has determined the estimated size, configuration, secondary waste streams, critical issues, and cost for the process in application to Department of Energy wastes. A summary of the results obtained thus far in process development is included here as Attachment 1.

In Phase II, now in progress, a developmental prototype process system will be designed. In Phase III the prototype will be fabricated and functionally tested. In Phase IV the prototype will be demonstrated with surrogate wastes and then with mixed waste.

Phase II is scheduled to be complete by September 1994. Phase III is estimated to be complete as of September 1995. Phase IV demonstration would be scheduled for FY 1996.

Demonstration site selection is planned to be made by July 1,1994. To support the site selection process, Delphi Research, Inc, and Morgantown Energy Technology Center are requesting information concerning waste problems in your domain which DETOX ${ }^{\mathrm{SM}}$ may be able to address, your schedule needs for waste treatment, the level of interest in a DETOXSM demonstration on your wastes, your anticipated requirements to support a demonstration (i.e., will you require separate funding and/or equipment?), and any other information which you deem appropriate to provide at this time.

The information you provide will be used to choose sites for more detailed discussion and survey for final selection. 
Mr. James Taylor

94-PMD-L050

April 7, 1994

Page 2 of 2

Thank you for your time and attention in this matter. We are looking forward to a successful demonstration of DETOX ${ }^{S M}$, leading to subsequent application and commercialization. I will be presenting DETOXSM at the Mixed Waste Integrated Program review meeting in Germantown April 19 21, or you can contact me before then at (505) 243-3111. The technical contact at Morgantown Energy Technology Center is V. P. Kothari, phone (304) 291-4579.

Sincerely,

DELPHI RESEARCH, INC.

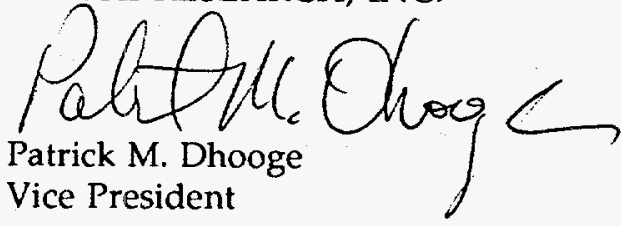

PDM:klt

Attachment: as stated 


\section{Distribution List}

Jim Taylor

DOE HQ

301/903-7234

Clyde Frank

DOE HQ

202/586-6773

Jill Lytle

DOE HQ

202/586-0449

Willis Bixby

DOE HQ

202/586-5393

Roger "Pat" Whitfield

DOE HQ

202/586-6523

Jim Schutte

DOE HQ

301/903-7457

Paul Hart

DOE Germantown

301/903-7457

Jan Berry

Oak Ridge National Laboratory

615/576-7865

Rob Smith

Jacobs Engineering

803/534-2457

Steve Stein

PNL

206/528-3552

Larry Paradee

Pantex

806/477-6472
John Steele

Westinghouse SRC

803/725-1660

Kimberly Nuhfer

Westinghouse Materials Co. of Ohio 513/648-6914

Greg Berlin

EM-50

509/376-9746

Roger Kuhl

INEL

208/526-5142

Blaire Brown

EG\&G Idaho

208/526-8861

John Gill

EG\&G Mound

513/865-3679

George Snyder

US DOE Idaho Falls

208/526-1184

Brack Hazen

Fermco

513/648-6915

Roger Gilchrist

Technology Demonstration Programs 509/376-9964

T. Abraham

Oak Ridge National Laboratory

615/576-6222

S. Anderson

Rocky Flats Plant

303/273-6245 
A. Browne

Energetics

301/621-8997 (f)

Ms. Julie Conner

INEL

208/526-6802

B. Daughtery

Savannah River Site

803/557-6306

K. Daum

INEL

208/526-6852

F. Delozier

Oak Ridge National Laboratory

615/576-4048

D. Eaton

INEL

208/526-7700

T. Hunter

Sandia National Laboratory

505/844-7437

J. Ludowise

WHC

509/376-6476

S. McMullen

Savannah River Site

803/644-6922

S. Meacham

Oak Ridge National Laboratory

615/435-3738

C. Peterson

WHC

509/372-1164
F. Delozier

Oak Ridge National Laboratory

615/576-4048

W. Sato

INEL

208/526-1184

J. Straalsund

PNL

509/373-0628

Guy Lussiez

University of California

Los Alamos National Laboratory

505/665-3750

Tom Connally

Oak Ridge National Laboratory

615/576-7865

Greg Pennington

Savannah River Site

706/860-6097

Phillip Gray

EG\&G Idaho

208/526-7700 
Attachment 3

$-39-$ 
$-40-$ 
Site Response Letters 
$-42-$ 


\author{
Department of Energy \\ Savannah River Operations Office \\ P.O. Box A \\ Aiken, South Carolina 29802
}

\title{
MAY 271994
}

Mr. Terry Rogers, President

Delphi Research, Inc.

701 Haines Avenue, N.W.

Albuquerque, NM 87102

Dear Mr. Rogers:

This letter represents the requested Letter of Intent to act as host site for a demonstration of the Delphi Research DETOXSM waste treatment technology. John Patterson, having visited your facility in Albuquerque, has briefed me on your alternative to incineration. It is our understanding that the facilities and wastes available at the Savannah River Site (SRS) are conducive to an effective demonstration of the technology. The use of SRS capabilities to perform demonstration testing of innovative environmental technologies is consistent with the mission and strategic vision for the site.

Westinghouse Savannah River Company will be the principal interface for arrangements associated with the testing. As indicated in Mr. Schwallie's letter to you, Dr. Jack Corey will be the lead person to assure that infrastructure and regulatory requirements have been satisfactorily addressed.

We look forward to a successful partnership in iec'́nology demonstration.

Sincerely,

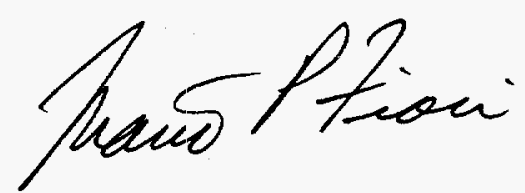

Mario P. Fiori

Manager

cc: Ambrose Schwallie, WSRC

Jack Corey, WSRC 


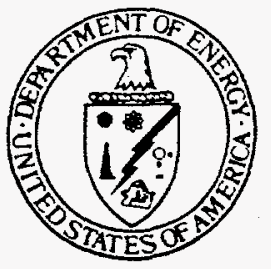

\author{
Department of Energy \\ Oak Ridge Operations \\ Weldon Spring Site \\ Remedial Action Project Office \\ 7295 Highway 94 South \\ St. Charles, Missouri 63304
}

May 17, 1994

Mr. Terry Rogers

Delphi Research, Inc.

701 Haines Avenue, NW

Albuquerque, New Mexico 87102

Dear Mr. Rogers:

\title{
DELPHI DETOX FIELD DEMONSTRATION
}

This correspondence is in response to the April 13, 1994 letter from Terry $W$. Rogers to Steve McCracken and to reaffirm the Weldon Spring Site Remedial Action Project's (WSSRAP) interest in supporting a field demonstration of Delphi Research, Inc.'s DETOX technology.

As requested, additional waste characterization information regarding WSSRAP mixed wastes is enclosed, which includes a copy of the WSSRAP mixed waste inventory with waste stream groupings and corresponding identification numbers. The waste streams to be considered for DETOX are marked with an asterisk. The waste profile sheets for the majority of the wastes are provided and are grouped by waste streams in corresponding order. To provide additional information, copies of the analytical data from the computer database are included with each waste stream group.

The WSSRAP is currently preparing waste profiles for polychlorinated biphenyl (PCB) wastes, to be submitted to you during your site visit on May 24, 1994.

The WSSRAP is interested in receiving the following information from Delphi Research, Inc., to assist in preparing the WSSRAP Draft and Final Site Treatment Plans: 1) cost, 2) schedule, 3) demonstration goals, 4) waste acceptance criteria, and 5) a list of WSSRAP wastes which can be treated by the DETOX process. 
We look forward to your visit to WSSRAP on May 24, 1994. If you have any questions, please contact Tom Pauling of my staff at 926-7051.

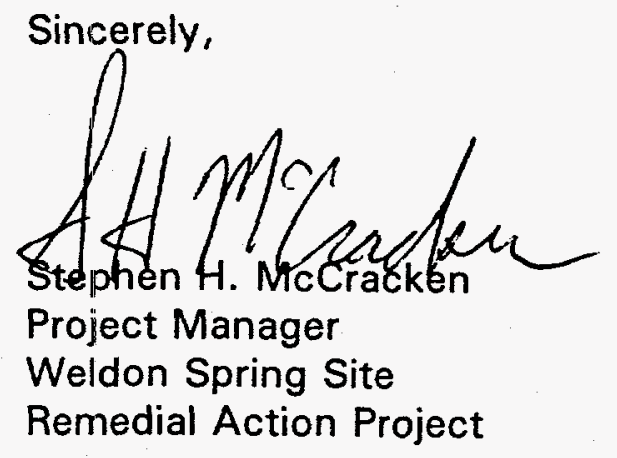

Enclosures:

As stated

cc w/o enclosures:

Harvey Rice, EW-92

Dan Tschirg, MDNR

Martha Kopper/Geri Kountzman, MDNR

Dan Wall, EPA 


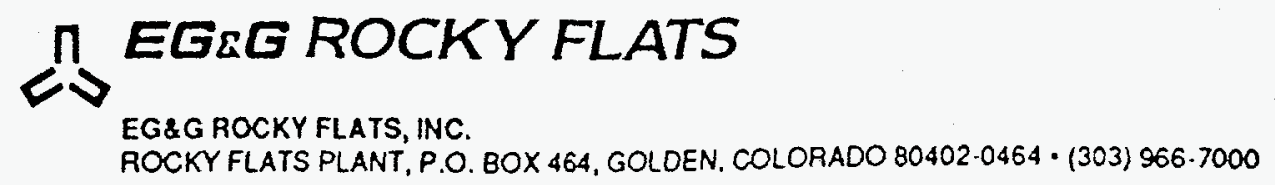

May 16, 1994

94 -RF-05612

Patrick M. Dhooge

Vice President

Delphi Research, Inc.

701 Haines Ave. N.W.

Albuquerque, NM 87102

\section{RESPONSE TO REQUEST FOR INFORMATION REGARDING ROCKY FLATS PLANT (RFP) MIXED WASTES - SAA-060-94}

In reference to your letter of April 12, 1994, EG\&G Rocky Flats continues to be interested in the Deiphi Research, Inc. DETOXsm process and in selection as the primary site for a field demonstration of this technology.

Three waste streams - FBI oil, solid combustibles, and PCB liquids - are proposed as the primary target wastes for this demonstration. The following table provides the wastes that RFP would be interested in testing using Treatability Study Exemptions (TSEs):

Analytical Lab Solutions
Excess Chemicals
Leaded Gloves/Acid Contaminated
Miscellaneous Liquids
Organics Discard Level
Solidified Organics

Combustibles
FBI Oil
Leaded Gloves
Organic Resins
Paints
Used Absorbents

It is determined that these specific wastes may have some direct treatment applicability under the DETOXsm process. Current information regarding all RFP low-level mixed waste streams, extracted from the March 31, 1994 Annual Land Disposal Restriction Progress Report, is attached in Appendix A (RFP Low-Level Mixed Waste Streams) and is provided to assist in evaluating which RFP wastes could be treated by this method.

Estimated costs for EG\&G's support of the field demonstration have been updated and detailed in Appendix B (Estimated Costs for a Hot Demonstration of the Delphi Catalytic Chemical Oxidation Process). These costs are substantially lower than previous estimates provided by EG\&G Rocky Flats, Technology Development. Earlier estimates assumed that the demonstration unit would be located in Building 777. Recent efforts to install a Low Temperature Thermal Desorption (LTTD) test unit (to test actual wastes under a TSE) identified the Tent 10 Permacon as a viable option for demonstrating innovative treatment technologies at Rocky Flats. Both the approval and installation costs for using the tent are lower than for using an operations building in the Protected Area. Detailed cost and schedule estimates have been drafted for the LTTD unit; these estimates were adapted for the DETOXsm process (Appendix B). 
Patrick M. Dhooge

May 16, 1994

94-RF-05612

Page 2

The estimated cost for EG\&G Rocky Flats support of this demonstration is approximately $\$ 1.6$ million for testing three waste streams. Previous estimates were $\$ 2.2$ million for three tests. The cost for each additional waste stream is $\$ 225 \mathrm{~K}$ with both labor and non-labor costs.

The FY96 Delphi initiation date is achievable for demonstration at Rocky Flats. DETOXsm is one of six technologies already under consideration as an alternative to incineration.

If you have questions on the cost estimate or RFP waste information, contact me at (303)273-6164 or C.M. Brown at (303)966-5277.

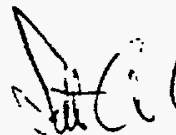<smiles>CCCCC</smiles>

Scott A. Anderson, Manager

Federal Facility Compliance Agreement Programs

EG\&G Rocky Flats, Inc.

$\cos$

Attachments

As Stated (2) 
May 27, 1994

Mr. Terry Rogers, President

Delphi Research, Inc.

Chemical Research \& Development

701 Haines Avenue, N.W.

Albuquerque, NM 87102

Dear Mr. Rogers:

Ref: Your letter dated, May 23, 1994, Requesting a Letter of Intent from DOE-SR and WSPC for the Savannah River Site to Participate as a DETOX SM Demonstration Site

Thank you for your letter expressing interest in having the Savannah River Site (SRS) participate as a DETOXSM Demonstration Site.

It appears from initial reviews, that the Savannah River Site would be a compatible host site and we would like to express our interest and support in hosting the DETOXSM demonstration unit.

If SRS is selected to participate as a demonstration site, details of financial amangements, facility support requirements and logistics associated with training. safety, compliance and conduct of operations would need to be further developed.

Mr. John Patterson, DOE-SR, (803-725-5831) and Dr. Jack Corey, WSRC, (803-7251134) will have the lead in coordinating this demonstration effort. Please contact them if you need additional information.

Again, thank you for your interest in the Savannah River Site. We look forward to working with Delphi Research, Inc. and DOE-Morgantown Energy Technology Center in further developing this important technology.

Sincerely yours,

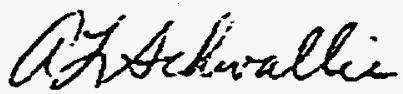

Ambrose Schwallie, President Westinghouse Savannah River Company

AS:ka

CC: M. P. Frori-DOE-SR, 703-A

J. R. Patterson - DOE-SR, 703-46A

G. A. Krist - WSRC, 703-A

C. M. Hammond - WSAC, 703-A 


$\begin{array}{ll}\text { TO: } & \text { Patrick M. Dhooge } \\ & \text { Delphi Research, Inc. } \\ \text { FROH: } & \text { Dean D. Taylor } \\ & \text { Environmental Engineering Unit } \\ & \text { EG\&G Idaho, Inc. } \\ \text { P.0. Box } 1625 \text {, MS } 3509 \\ \text { Idaho Falls, ID } 83415 \\ \text { Ph. (208) } 526-9744 \\ \text { FAX (208) 526-2847 }\end{array}$

Dave Eaton received your FAX of April 12, describing the DETOX process, and suggested that I look at it in light of an effort I am currently involved with to identify private sector capabilities to address some specific needs in waste management at the INEL. It sounds as if the process you describe may have application to some of our mixed waste streams. However, after reading the process description which states:

"While DETOX may not provide stand-alone treatment..., it can be valuable in reducing the volume of "..mixed wastes, and in converting mixed wastes to a radioactive-only form."

and examining the data for the two examples provided (radioactively contaminated PCB oils, and radioactively contaminated tributyl phosphate with PCBs and mercury), the applicability of the above statement was not clear, particularly the part about separation of RCRA metals from radioactive metals in the secondary waste streams. Later on the following statement is made:

"If the extractable toxic metal content of the residue is above RCRA levels for a hazardous waste, it would be stabilized to a suitable low level radioactive-only waste form for disposal."

Can you be more specific about how this metals separation is effected, and the separation efficiencies that have actually been achieved in practice?

You can call or FAX me the information at the above numbers.

Thank you.

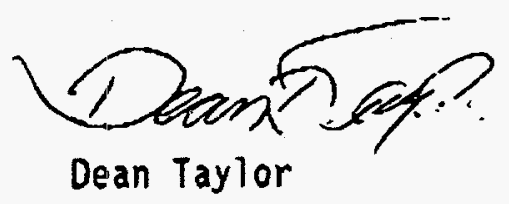


$-50-$ 
Attachment 4 
$-52-$ 


\section{Primary Site Contacts}

Hanford

Weldon Spring

Rocky Flats Plant
Richland Operations Office

a. Deborah E. Trader (TPO)

U. S. Department of Energy

Richland Operations Office

P. O. Box 550, MS K8-50

* 3230 Q Avenue

Richland, WA 99352

509/372-4035

$509 / 372-4037$ (fax)

b. James Berger (TPM) or Greg Berlin

Office of Technology Integration

Westinghouse Hanford

${ }^{*} \mathrm{c} / \mathrm{o}$ Westinghouse Receiving

* 2355 Steven Drive

P. O. Box 1970, MS L0-18

Richland, WA 99352

509/376-9942

509/372-0623 (Berlin)

509/376-9746 (fax)

a. Steve McCracken

U. S. Department of Energy

7295 Highway 94 South

St. Charles, MO 63304

314/441-8086, ext. 7001

$314 / 447-0739$ (fax)

b. David Hixson

7295 Highway 94 South

St. Charles, MO 63304

314/441-8086, ext. 3110

$314 / 447-0803$ (fax)

Rocky Flats Operations Office

a. Sheri L. Rudolph (TPO)

U.S. Department of Energy

Rocky Flats Office

P. O. Box 928 , Highway 93

* DOE Building T124A

Golden, CO 80402-0928

303/966-5788

303/966-2256 (fax) 
Rocky Flats Plant (cont:)

Savannah River

Idaho b. Jerry L. Peterson (TPM)

EG\&G Rocky Flats, Inc.

Technology Development, Building T130B

P. O. Box 464

Golden, CO 80402-0464

303/966-5342

303/966-3407 (fax)

c. Charles Brown

EG\&G Rocky Flats, Inc.

Rocky Flats Plant

Technical Investigations Group, Building 881

P. O. Box 464

Golden, $\mathrm{CO}$ 80402-0464

303/966-5277

Savannah River Operations Office

a. Michael O'Rear (TPO)

U.S. Department of Energy

Savannah River Operations Office

P. O. Box A

* RFD \#1, Building 703A, Room E-208N

Aiken, SC 29802

803/725-5541

803/725-3616 (fax)

b. John Steele (TPM)

Waste Environmental Remediation Programs

Savannah River Site

Building 773-A, A208

Aiken, SC 29802

803/725-1830

$803 / 725-1660$ (fax)

Idaho Operations Office

a. Thomas E. Williams (TPO)

U.S. Department of Energy

Idaho Operations Office

MS 1219

785 DOE Place

Idaho Falls, ID 83402

208/526-2460

208/526-6249 (fax)

b. Lloyd W. McClure (TPM)

Westinghouse Idaho Nuclear Co.

* INEL Research Center

* 2151 North Blvd.

P. O. Box 4000

Idaho Falls, ID 83415-2202

208/526-1170

208/526-1390 (fax) 
Idaho (cont.)

Los Alamos

Fernald

* Federal Express Address c. Ken Merrill (TPM)

Waste Technology Development

EG\&G Idaho, Inc.

* 2525 Freemont Drive

P. O. Box 1625, MS 3710

Idaho Falls, ID 83415-3710

208/526-0797

208/526-5142 (fax)

Los Alamos National Laboratory

a. Bruce Erdal (TPM)

ET-AET

Los Alamos National Laboratory

MS D446

Los Alamos, NM 87545

505/667-5338

505/665-4355 (fax)

b. Guy Lussiez

University of California

Los Alamos National Laboratory

P. O. Box 990 MS 517

Los Alamos, NM 87545

505/667-7391

505/665-3750 (fax)

a. Rod Warner (TPO)

U.S. Department of Energy

Administrative Building

P. O. Box 398705

Cincinnati, $\mathrm{OH} \quad$ 45239-8705

* 7400 Willey Road

* Fernald, $\mathrm{OH} 45030$

513/648-3156

513/648-3076 (fax)

b. Paul Pettit (TPM)

FERMCO

P. O. Box 398784 , MS- 81

Cincinnati, $\mathrm{OH} \quad 45239-8784$

* 25 Merchant Street, MS-81

* Springdale, $\mathrm{OH} 45246$

513/648-6558

513/648-6913 (fax) 
$-56-$ 
Attachment 5 
$-58-$ 


\section{Demonstration Site Identification Criteria for Environmental Restoration and Waste Management Technology Development Projects}

\section{Introduction}

DOE's Morgantown Energy Technology Center (METC) supports the Environmental Restoration and Waste Management (EM)-Office of Technology Development (EM-50) by contracting for research and development of technologies for waste site characterization and cleanup. The goal of this program is to develop and demonstrate new or improved technologies for addressing DOE's ER\&WM needs and to make those technologies known and available where needed across the DOE complex. METC responsibilities in this program include technology needs identification, procurement, project management, field demonstration, technology transfer, and support to transfer of technologies to the commercial sector. Project success will ultimately require demonstration of the technology at an appropriate DOE site.

Demonstration site identification is a key decision in obtaining programmatic success since it impacts on all aspects of each project, it guides the planning in the initial project phase, provides a basis for Go/No-Go decisions for continuation of the project, and drives the planning for subsequent phases. Therefore, site identification, negotiation, and planning must be made as early in the project life cycle as possible. It is the objective of METC to initiate the site identification process during Phase I of a project. Where possible, site identification will be made at the close of Phase I. In other cases, the close of Phase I will support the evaluation of alternative demonstration sites, and site identification will be made subsequent to Phase I but prior to award and implementation of Phases II and III.

Site identification involves the consideration, evaluation, and weighing of a variety of issues, goals and objectives, and must be directed by appropriate and sound criteria. This document identifies the major criteria, and discusses their application.

\section{Identification Criteria}

Seven primary criteria have been delineated for identification of a demonstration site. While all of the seven criteria are considered to be important, they are not listed in order of priority. An overriding order of priority has not been established, because the relative importance of any criterion may vary from project to project, depending on the nature of the demonstration project and/or the technology involved. Thus, prioritization of site-selection criteria will receive consideration upon initiation of the site identification process. The seven criteria are:

1. There must be a defined and documented site need for the technology.

2. The technical approach must be applicable and feasible for efficient performance at the site.

3. The regulatory status of the facility and compatibility of established regulatory schedules and constraints that apply to the site must not unreasonably limit the feasibility of a successful project demonstration. 
4. Technical, scientific, commercial and operational factors that lead to the preference of a specific site by the technology development contractor must be considered.

5. The potential for the demonstration to show applicability of the technology at other sites or throughout the weapons complex must be determined, and considered.

6. The costs associated with conduct of demonstration at alternative sites must be considered in order to assure cost effectiveness. The availability and source of funding must be established.

7. The site must demonstrate its willingness, technical ability, and adequate organizational structure to support the demonstration project.

The following discussion elaborates on each of the above criteria.

Criterion 1. There must be a defined and documented site need for the technology. In order to support a decision to commit funding and resources to an on-site small scale and eventual full scale demonstration, it is necessary to establish that the basis of the proposed project will provide for resolution of an identified need. By clearly defining the needs of the end user, clear objectives and performance goals by which the success of the demonstration can be measured will be established. A major criterion must be that the technology can be applied to resolution of an identified problem. The test plan can then be developed so that the maximum probability of transferring a proven technology to a practical field application is assured.

Criterion 2. The technical approach must be applicable and feasible for efficient performance at the Site. The technical applicability and feasibility of demonstrating the project technology at the site must be considered and verified. A technology that potentially will work very well at one site may well be a failure at another due to differences in site conditions. Differences in site conditions could include, for example, waste matrices, range of contaminants, contaminant concentrations and characteristics, geological and meteorological conditions, and clean-up levels or goals.

Criterion 3. The regulatory status of the facility and compatibility of established regulatory schedules and constraints that apply to the site must not unreasonably limit the feasibility of a successful project demonstration. The regulatory status of the potential site and the compatibility of the technology development project schedule with the site schedules for regulatory compliance, including characterization and remediation, must be evaluated and properly weighed in site identification decisions. The need and ability to obtain the necessary regulatory permits, whether the site is under CERCLA or RCRA, the requirements for NEPA documentation, and the requirements of a Federal Facility Compliance Agreement will all affect site identification

Criterion 4. Technical, scientific, commercial and operational factors that lead to the preference of a specific site by the technology development contractor must be considered. In certain cases, a technology development contractor may have previously established a strong understanding of the requirements of a specific site remediation program and the prevailing site conditions, and may have previously structured his research and development program to address the specific concerns. This situation is particularly apparent if a contractor has been working at a site utilizing the existing state-of-the-art, and has developed more advanced concepts. A contractor may also make the case that the conditions at the proposed site offer the greatest potential for developing a commercially viable (profitable) piece of equipment, instrument, or treatment process.

Criterion 5. The potential for the demonstration to show applicability of the technology at other sites or throughout the weapons complex must be determined, and considered. An important consideration in site identification is the multiple applicability of a technology to the DOE complex resulting from a demonstration at a given site. Would the demonstration results be applicable to a variety of needs at a 
number of sites, or would it only solve a limited or specific problem? To the extent that multiple applicability has been identified, site identification should lead to the development of a Demonstration Test Plan that will ensure the generation of adequate data to support a determination that the technology has applicability to other sites across the DOE complex, and that the results of the demonstration can be applied to other sites.

Criterion 6. The costs associated with conduct of demonstration at alternative sites must be considered in order to assure cost effectiveness. The availability and source of funding must be established. It is recognized that life cycle costs associated with the conduct of a demonstration may significantly differ between sites. Such differences may derive from costs for utilities, logistics, permitting, sampling and analysis, mobilization, etc. These differences may affect the cost effectiveness of the demonstration. In addition, the site specific demonstration costs must be evaluated in comparison with the availability of budgeted funding.

Criterion 7. The site must demonstrate its willingness, technical ability, and adequate organizational structure to support the demonstration project. Successful demonstration of a technology project requires active and effective support from DOE management at the facility, the Management and Operating contractor, and other support organizations. Accordingly, a particular site's technical or scientific background relative to the nature of the problem and the proposed technology application must be considered. The facility's technical and administrative resources and past experience in demonstrating projects of similar scope and complexity will be considered to be an important element in the ultimate success of the demonstration project.

\section{Site Identification Process}

In order to ensure that the application of new technologies will receive the acceptance and support of all affected parties, it is essential that a process of open discussion and involvement in the process is adopted. The active support of many organizations across the DOE complex facilitates and accelerates the successful demonstration of a technology development project. The comments and recommendations of all affected parties will be actively sought throughout the demonstration site identification process, and will be appropriately utilized for all METC site decisions. Affected parties include, but may not be limited to: the technology development contractor, Environmental Restoration or Waste Management division at the DOE Operations Office, Technology Development division at the DOE Operations Office, EM 30 or EM-40, EM-50, Site M \& O or ERM contractor, and Stakeholders and Regulators.

In particular, it must be recognized that the Regulators and the Stakeholders will have a significant impact on the final selection, since the ultimate use of the technology at a particular site must receive their approval. It also must be recognized that there are significant differences in the administrative approach of the different regions of the U.S. EPA, and in the states towards the adoption and implementation of innovative technologies at DOE sites.

Each technology project must be viewed as unique as the site identification process continues to a decision. The major criteria form the basis for guiding this process and for moving forward. Final site identification will be made based upon METC's assessment of the optimum potential for project success and maximum benefit to the goals of the ERWM program. 
$-62-$ 
Attachment 6

$-63-$ 
$-64-$ 


\section{Delphi Research, Inc. Site Selection Criteria and Evaluation Factors* for the DETOXSM Waste Treatment Unit Field Demonstration}

\section{Selection Criteria}

In order for a site to qualify as a DETOX ${ }^{\mathrm{SM}}$ demonstration site, the site must:

1. Have wastes suitable for DETOX ${ }^{5 M}$.

Rationale: Even though DETOX ${ }^{\mathrm{SM}}$ has the potential to treat a larger variety of wastes, we plan to limit the demonstration to wastes similar to the ones which have been used in our laboratory bench scale tests.

2. Permit access to the site.

Rationale: Overly restrictive access requirements will hinder demonstration activities. Delphi Research and our engineering support contractor are well aware of the significance of conducting this type of demonstration on a DOE site. We view this demonstration as a privilege, not a right, and will closely adhere to all safety, security, and regulatory compliance requirements.

3. Provide or facilitate site-specific support, (e.g., electricity, water, air conditioning, training for safety, security, and regulatory compliance, etc.).

Rationale: Site personnel are the experts and authorities on local requirements and support capabilities.

\section{Evaluation Factors}

The following is Delphi's initial prioritized list of evaluation factors:

1. Site interest in hosting the demonstration.

2. Site regulatory requirements.

3. Scheduling.

4. Cost to the project.
a. Cost for site support
b. Transportation
c. Travel cost
d. Communication/coordination cost

5. Site waste types are representative of several DOE sites.

6. Site access restrictions.

* These criteria and factors are being used by Delphi to prepare the Site Selection Report, not the DOE site selection criteria. 
$-66-$ 


\section{Attachment 7}

$-67-$ 


$$
-68-
$$




\section{Index of DETOXSM Priority \\ Waste Types by Site}

Source: $\quad$ Interim Mixed Waste Inventory Report (IMWIR) provided by Los Alamos National Laboratory

Note: $\quad$ Sites are not in priority order, but wastes at each site are listed in priority order. Waste identification numbers are from the IMWIR. 


\begin{tabular}{|c|c|c|}
\hline Site & Waste Type & ID Number \\
\hline Rocky Flats Plant & $\begin{array}{ll}\text { 1. } & \text { FBI Oil } \\
\text { 2. } & \text { Combustibles } \\
\text { 3. } & \text { Particulate-Sludge }\end{array}$ & $\begin{array}{l}336 \\
111 \\
355\end{array}$ \\
\hline Savannah River Site & $\begin{array}{l}\text { 1. Tri-butylphosphate and N-paraffin } \\
\text { 2. DWPF Benzene } \\
\text { 3. Solvent Waste }<100 \mathrm{NCI} / \mathrm{g} \text { TRURAD }\end{array}$ & $\begin{array}{c}0000002696 \\
884 \\
910\end{array}$ \\
\hline Hanford Site & $\begin{array}{l}\text { 1. TC Metal Organic Solid Debris } \\
\text { 2. TC Metal Organic Solid Debris (CA) } \\
\text { 3. Non-TC Metal/Solvent Organic Solid } \\
\text { Debris }\end{array}$ & $\begin{array}{l}932 \\
933 \\
945\end{array}$ \\
\hline Fernald & $\begin{array}{l}\text { 1. Contaminated Insoluble Oil } \\
\text { 2. Contaminated Oil, Insoluble } \\
\text { 3. Sludges, Oily, for Oxidation High Free }\end{array}$ & $\begin{array}{l}0000010029 \\
0000010027 \\
0000060119\end{array}$ \\
\hline INEL & $\begin{array}{l}\text { 1. Tan Decon Solvents Wastes } \\
\text { 2. Scrub Pump Radioactive Oil } \\
\text { 3. Heavy Metal Radioactive Oil }\end{array}$ & $\begin{array}{r}\text { ID-EGG-162 } \\
\text { ID-WIN-217 } \\
\text { ID-EGG-217 }\end{array}$ \\
\hline Weldon Spring Site & $\begin{array}{l}\text { 1. Oil/Solvents with Lead } \\
\text { 2. Organic Liquids with Lead (D008-Liquids) } \\
\text { 3. Ethylene Glycol with TCE }\end{array}$ & $\begin{array}{c}2250 \\
471 \\
2246\end{array}$ \\
\hline Los Alamos National Laboratory & $\begin{array}{l}\text { 1. Ignitable Liquids } \\
\text { 2a. Spent Solvents - F003 } \\
\text { 2b. Spent Solvents - F002 } \\
\text { 2c. Spent Solvents - F005 }\end{array}$ & $\begin{array}{l}0000002055 \\
0000002180 \\
0000002176 \\
0000002184\end{array}$ \\
\hline
\end{tabular}


State: Colorado

Site: ROCKY FLATS PLANT

Waste Stream Name: FBI OIL (LLW-MIXED)

Matrix: Organic Liquids
ID \# :

336

Waste Type: MLIW

Waste Stream Description and Source:

This waste stream was previously named "FBI Oil." IDC No.

$\mathrm{N} / \mathrm{A}$ This waste stream is low-level mixed waste oil

consisting of radiologically contamined spent cutting

fluids, hydraulic oils, and lubricating oils from various

operations on plant site. This oil is also contaminated

with spent solvents such as carbon tetrachloride and freon.

FBI oil is being stored in two large tanks in Building 774

with the remainder being stored in 55-gallon drums.

\begin{tabular}{|c|c|c|c|c|c|c|c|}
\hline \multicolumn{6}{|c|}{$\begin{array}{l}\text { Current Inventory as } \\
\text { of December } 31,1992\end{array}$} & \multirow{2}{*}{\multicolumn{2}{|c|}{$\begin{array}{l}\text { PROJECTED } \\
\text { GENERATION } \\
1993 \text { THROUGH } \\
1997\end{array}$}} \\
\hline \multicolumn{2}{|c|}{$\begin{array}{l}\text { Not Subject To } \\
\text { LDR Prohibition }\end{array}$} & \multicolumn{2}{|c|}{$\begin{array}{l}\text { SUBJECT TO } \\
\text { LDR Prohibition }\end{array}$} & \multicolumn{2}{|c|}{ TOTAL } & & \\
\hline $\begin{array}{l}\text { Cubic } \\
\text { Meter }\end{array}$ & $\mathrm{kg}$ & $\begin{array}{l}\text { Cubic } \\
\text { Meter }\end{array}$ & $\mathrm{kg}$ & $\begin{array}{l}\text { Cubic } \\
\text { Meter }\end{array}$ & $\mathrm{kg}$ & $\begin{array}{l}\text { Cubic } \\
\text { Meter }\end{array}$ & $\mathrm{kg}$ \\
\hline 0.000 & - & 109.6 & - & 109.6 & - & 0.000 & 0.000 \\
\hline
\end{tabular}

Treatability Group:

MLLW CH/AL, Organic Liquids, Toxic Organics and Metals w/ Mercury

Treatment status:

Plan to treat at a planned facility.

Plans are described in the Comprehensive Treatment and

Management Plan dated June 9, 1992.

Technology status:

Technology exists. Needs modifications or verification for

application to DOE waste streams.

Radiation Characteristics:

1) Alpha emitter, 10-100 nCi/g

2) Contact-handled

3) Alpha emitter, $<10 \mathrm{nCi} / \mathrm{g}$

Waste Specific Radiation Effects on Treatment:

1) None. 
State: Colorado

ID \# :

336

Site: ROCKY FLATS PLANT

Waste stream Name: FBI OIL (LLW-MIXED)

Matrix: Organic Liquids

Waste Type: MLLW

Waste Minimization Activitiies:

1) Technology changes: process changes; equipment, piping - or layout changes; automation; changes in operation al settings; and energy, water conservation.

2) Waste avoidance due to recycling/reuse: solvent, oil, a nd metals recycling; chemical exchange and reuse; and packaging material reuse.

3) Change in operations status; process interruptions; wo rk stoppages; mission changes; and new processes.

General Comments:

Basis of estimate past 3 year generation history.

RCRA CODES

Waste Charcterization Basis: Process Knowledge

\begin{tabular}{|c|c|c|}
\hline Waste Codes & IDR Basis & Best Demonstrated Available Technologies \\
\hline D001A & Tech. & $\begin{array}{l}\text { Fuel Substitution; Organics Recovery; or I } \\
\text { ncineration }\end{array}$ \\
\hline D007 & Conc. & $\begin{array}{l}\text { Chemical Reduction followed by stabilizatio } \\
\mathrm{n}\end{array}$ \\
\hline Do08B & Conc. & stabilization \\
\hline Do09C & Conc. & $\begin{array}{l}\text { Thermal Recovery of Metals: Acid Leaching; } \\
\text { Stabilization; or Incineration }\end{array}$ \\
\hline F001 & Conc. & Incineration \\
\hline F002 & Conc. & Incineration \\
\hline F003 & Conc. & Incineration \\
\hline F005A & Conc. & Incineration \\
\hline
\end{tabular}


State: Colorado

ID \# :

111

site: ROCKY FLATS PLANT

Waste Stream Name: COMBUSTIBLES/LLW MIXED

Matrix: Inorganic Debris

Waste Type: MLLW

Waste Stream Description and Source:

Combustibles are generated at numerous locations throughout

the RFP and are generally composed of such materials as paper, cloth, and plastics. The material is contaminated at low concentrations with depleted uranium or plutonium through contact during manufacturing and related processes. The materials making up this waste are items that have been used to wipe off products being machined, cleaned, or otherwise handled. The waste is packaged in 55-gal. drums with multiple bag liners. In addition, combustibles can be packaged in plywood boxes with PVC liners. This waste is identified by IDCs $325,330,336,851,852$, and 853 . Some containers may contain smali amounts of glass and metal waste.

\begin{tabular}{|c|c|c|c|c|c|c|c|}
\hline & & $\begin{array}{l}\text { irrent } \\
\text { Decen }\end{array}$ & $\begin{array}{l}\text { ventory } \\
=31,19\end{array}$ & & & \multirow{2}{*}{\multicolumn{2}{|c|}{$\begin{array}{l}\text { PROJECTED } \\
\text { GENERATION } \\
1993 \text { THROUGH } \\
1997\end{array}$}} \\
\hline \multicolumn{2}{|c|}{$\begin{array}{l}\text { Not Subject To } \\
\text { LDR Prohibition }\end{array}$} & \multicolumn{2}{|c|}{$\begin{array}{l}\text { SUBJECT TO } \\
\text { LDR Prohibition }\end{array}$} & \multicolumn{2}{|c|}{ TOTAL } & & \\
\hline $\begin{array}{l}\text { Cubic } \\
\text { Meter }\end{array}$ & $\mathrm{kg}$ & $\begin{array}{l}\text { Cubic } \\
\text { Meter }\end{array}$ & $\mathrm{kg}$ & $\begin{array}{l}\text { Cubic } \\
\text { Meter }\end{array}$ & $\mathrm{kg}$ & $\begin{array}{l}\text { Cubic } \\
\text { Meter }\end{array}$ & $\mathrm{kg}$ \\
\hline 0.000 & - & 410.4 & - & 410.4 & - & 263.1 & - \\
\hline
\end{tabular}

Treatability Group:

MLLW CH/AL, Inorganic Debris, Toxic Organics

Treatment status:

Plan to treat at a planned facility.

Plans are described in the comprehensive Treatment and

Management Plan dated June 9, 1992.

Technology status:

Technology exists. Needs modifications or verification for application to DOE waste streams.

Radiation Characteristics:

1) Alpha emitter, 10-100 $\mathrm{nCi} / \mathrm{g}$

2) Alpha emitter, < $10 \mathrm{nCi} / \mathrm{g}$

3) Contact-handled 
State: Colorado

ID \# :

111

Site: ROCKY FLATS PLANT

Waste Stream Name: COMBUSTIBLES/LLW MIXED

Matrix: Inorganic Debris

Waste Type: MLLW

Waste Specific Radiation Effects on Treatment:

1) High alpha activity in contact with organics or water c an result in radiolysis, with production of hydrogen ga $s$, methane and other degradation products. The buildup of hydrogen gas and radiation interaction with the was te form can affect storage, design

and operation of treatment facilities, and stability 0 $f$ the final waste form.

Waste Minimization Activitiies:

1) Improved operating practices: changes in material handl ing and inventory procedures; waste segregation; and changes in production scheduling.

2) Technology changes: process changes; equipment, piping , or layout changes; automation; changes in operation al settings; and energy, water conservation.

3) Change in operations status; process interruptions; wo rk stoppages; mission changes; and new processes.

General Comments:

Basis of estimate past 3 year generation history. Generation includes waste expected from Bldg 771 Duct Remediation (assuming full funding).

RCRA CODES

Waste Charcterization Basis: Process Knowledge

\begin{tabular}{|l|l|l|}
\hline Waste Codes & LDR Basis & Best Demonstrated Available Technologies \\
\hline F001 & Conc. & Incineration \\
\hline F002 & Conc. & Incineration \\
\hline F005A & Conc. & Incineration \\
\hline
\end{tabular}

The alternate LDR treatment standards for debris is treatment prior to land disposal using any of the following technologies: extraction (physical - chemical or thermal), destruction(biological, chemical, or thermal), macro/microencapsulation or sealing. 
State: Colorado

Site: ROCKY FLATS PLANT

Waste Stream Name: PARTICULATE-SLUDGE/LLW MIXED

Matrix: Inorganic Sludges/Particulates
ID \# :

355

Waste Type: MLLW

Waste Stream Description and Source:

This waste stream was not specifically identified in either the storage or Inventory Reports prepared by Rocky Flats in fulfillment of FFCA requirements. This waste was a portion of the stream entitled "Particulate Sludge Waste/Tru Mixed" in the Inventory Report. Normally the waste was TRU, but some was found to be LLW. IDC Nos. 292, 299, 332, $430,431$. This waste was generated from plutonium recovery operations in Building 771. The waste consisted of incineration sludge (IDC 292), miscellaneous sludge (IDC 299), oily sludge (IDC 332), unleached resin (IDC 430 and leached resin (IDC 431). The particulate and sludge wastes (TRU mixed) discussed in the National Report on Prohibited Wastes and Treatment options and in Treatment Report No 1 were unleached ion exchange resin (IDC 431). Spent ion exchange resin waste was not included in this data. Wastes currently in storage are uncemented. The wastes are typically packaged in smaller containers within 55-gallon drums with multiple bag liners.

\begin{tabular}{|c|c|c|c|c|c|c|c|}
\hline \multicolumn{6}{|c|}{$\begin{array}{l}\text { Current Inventory as } \\
\text { of December } 31,1992\end{array}$} & \multirow{2}{*}{\multicolumn{2}{|c|}{$\begin{array}{l}\text { PROJECTED } \\
\text { GENERATION } \\
1993 \text { THROUGH } \\
1997\end{array}$}} \\
\hline \multicolumn{2}{|c|}{$\begin{array}{l}\text { Not Subject To } \\
\text { LDR Prohibition }\end{array}$} & \multicolumn{2}{|c|}{$\begin{array}{l}\text { SUBJECT TO } \\
\text { LDR Prohibition }\end{array}$} & \multicolumn{2}{|c|}{ TOTAL } & & \\
\hline $\begin{array}{l}\text { Cubic } \\
\text { Meter }\end{array}$ & $\mathrm{kg}$ & $\begin{array}{l}\text { Cubic } \\
\text { Meter }\end{array}$ & $\mathrm{kg}$ & $\begin{array}{l}\text { Cubic } \\
\text { Meter }\end{array}$ & $\mathrm{kg}$ & $\begin{array}{l}\text { Cubic } \\
\text { Meter }\end{array}$ & $\mathrm{kg}$ \\
\hline 0.000 & - & 4.900 & - & 4.900 & - & 0.000 & 0.000 \\
\hline
\end{tabular}

Treatability Group:

MLLW CH/AL, Inorganic Sludges/Particulates, Toxic Organics and Metals w/o Mercury

Treatment status:

Plan to treat at a planned facility.

Plans are described in the Comprehensive Treatment and Management Plan dated June 9, 1992.

Technology status:

Technology exists. Needs modifications or verification for application to DOE waste streams. 
State: Colorado

Site: ROCKY FLATS PLANT

ID \# :

355

Waste stream Name: PARTICULATE-SLUDGE/LLW MIXED

Matrix: Inorganic Sludges/Particulates

Waste Type: MLLW

Radiation Characteristics:

1) Alpha emitter, 10-100 $\mathrm{nCi} / \mathrm{g}$

2) Alpha emitter, < $10 \mathrm{nci} / \mathrm{g}$

3) Contact-handled

Waste Specific Radiation Effects on Treatment:

1) High alpha activity in contact with organics or water $\mathbf{c}$ an result in radiolysis, with production of hydrogen ga $s$, methane and other degradation products. The buildup of hydrogen gas and radiation interaction with the was te form can affect storage, design

and operation of treatment facilities, and stability o $f$ the final waste form.

2) Radioactive decay may produce significant amounts of he at that needs to be considered during treatment and dis posal.

Waste Minimization Activitiies:

1) Not Applicable.

No longer generated.

General Comments:

RCRA CODES

Waste Charcterization Basis: Process Knowledge

\begin{tabular}{|c|c|c|}
\hline Waste Codes & LDR Basis & Best Demonstrated Available Technologies \\
\hline D001A & Tech. & $\begin{array}{l}\text { Fuel Substitution; Organics Recovery; or I } \\
\text { ncineration }\end{array}$ \\
\hline D006B & Conc. & Stabilization \\
\hline D007 & Conc. & $\begin{array}{l}\text { Chemical Reduction followed by stabilizatio } \\
\mathrm{n}\end{array}$ \\
\hline Do08B & Conc. & Stabilization \\
\hline F001 & Conc. & Incineration \\
\hline F002 & Conc. & Incineration \\
\hline $\mathrm{FOO3}$ & Conc. & Incineration \\
\hline
\end{tabular}

$05 / 17 / 94$ 
State: Colorado

Site: ROCKY FLATS PLANT

Waste stream Name: PARTICULATE-SLUDGE/LLW MIXED

Matrix: Inorganic Sludges/Particulates

ID \# :

355

Waste Type: MLLW

\begin{tabular}{|l|l|l|}
\hline F005A & Conc. & Incineration \\
\hline
\end{tabular}


State: South Carolina

Site: SAVANNAH RIVER SITE

ID \# 0000002696

Waste Stream Name: TRI-BUTYL-PHOSPHATE \& N-PARAFFIN

Matrix: Organic Liquids

Waste Type: MLLW

Waste Stream Description and Source:

Part of the purex process used in the separations areas (200-F and 200-H). An organic solvent resembling diesel fuel in appearance. Future plan for $\mathrm{F}$ - and $\mathrm{H}$-canyons shows about $340,194 \mathrm{~kg}$ of process material will become waste at time of decommissioning which is not expected within this 5-year time frame.

\begin{tabular}{|c|c|c|c|c|c|c|c|}
\hline \multicolumn{6}{|c|}{$\begin{array}{l}\text { Current Inventory as } \\
\text { of December } 31,1991\end{array}$} & \multirow{2}{*}{\multicolumn{2}{|c|}{$\begin{array}{l}\text { PROJECTED } \\
\text { GENERATION } \\
1992 \text { THROUGH } \\
1996\end{array}$}} \\
\hline \multicolumn{2}{|c|}{$\begin{array}{l}\text { Not Subject To } \\
\text { LDR Prohibition }\end{array}$} & \multicolumn{2}{|c|}{$\begin{array}{l}\text { SUBJECT TO } \\
\text { LDR Prohibition }\end{array}$} & \multicolumn{2}{|c|}{ TOTAL } & & \\
\hline $\begin{array}{l}\text { Cubic } \\
\text { Meter }\end{array}$ & $\mathrm{kg}$ & $\begin{array}{l}\text { Cubic } \\
\text { Meter }\end{array}$ & $\mathrm{kg}$ & $\begin{array}{l}\text { Cubic } \\
\text { Meter }\end{array}$ & $\mathrm{kg}$ & $\begin{array}{l}\text { Cubic } \\
\text { Meter }\end{array}$ & $\mathrm{kg}$ \\
\hline 89.60 & $8.337 \mathrm{E} \quad 4$ & 0.000 & 0.000 & 89.60 & $8.337 E \quad 4$ & 0.000 & 0.000 \\
\hline
\end{tabular}

Treatability Group:

MLLW CH/AL, Organic Liquids, Toxic Organics and Metals w/ Mercury

Treatment status:

Have not identified a planned facility for this waste stream at this time.

Treatment options are still being analyzed.

Technology status:

Technology assessment has not started.

Treatment technology exists (incineration) but needs modification to treat this waste.

Radiation Characteristics:

1) Contact-handled

2) Alpha emitter, 10-100 nCi/g

Waste Specific Radiation Effects on Treatment:

1) Certain isotopes of $\mathrm{U}, \mathrm{Pu}, \mathrm{Am}, \mathrm{Cm}, \mathrm{Cf}, \mathrm{Np}$ and $\mathrm{Th}$ are no n-accountable if present below specific levels, and req uire different levels of safeguards, depending on the a mount present. Treatments resulting in concentration o $f$ the material can result in the " 
State: South Carolina

ID \#: 0000002696

Site: SAVANNAH RIVER SITE

Waste Stream Name: TRI-BUTYL-PHOSPHATE \& N-PARAFFIN

Matrix: Organic Liquids

Waste Type: MLLW

roll up" of large volumes of non-accountable wastes int o a smaller volume of accountable waste or change a mix ed low-level waste to a TRU waste.

2) Radioactive decay may produce significant amounts of he at that needs to be considered during treatment and dis posal.

Waste Minimization Activitiies:

1) Change in operations status; process interruptions; wo rk stoppages; mission changes; and new processes.

General Comments:

RCRA CODES

Waste Charcterization Basis: Sampling Analysis

\begin{tabular}{|c|c|c|}
\hline Waste Codes & LDR Basis & Best Demonstrated Available Technologies \\
\hline D008B & Conc. & Stabilization \\
\hline Do09C & Conc. & $\begin{array}{l}\text { Thermal Recovery of Metals; Acid Leaching; } \\
\text { Stabilization; or Incineration }\end{array}$ \\
\hline D010 & Conc. & stabilization \\
\hline D011 & Conc. & Stabilization \\
\hline D018 & & $\begin{array}{l}\text { Not currently prohibited under the LDR Prog } \\
\text { ram. }\end{array}$ \\
\hline D035 & & $\begin{array}{l}\text { Not currently prohibited under the LDR Prog } \\
\text { ram. }\end{array}$ \\
\hline
\end{tabular}


state: South Carolina

ID \# :

884

Site: SAVANNAH RIVER SITE

Waste Stream Name: DWPF BENZENE

Matrix: Organic Liquids

Waste Type: MLLW

Waste stream Description and Source:

Future waste stream. This waste will be generated from DWPF operations to vitrify HLW. The reaction between the precipitate slurry and the process feed chemicals within the precipitate reactor will liberate benzene from the slurry. The tetraphenylborate compounds will decompose in the presence of formic acid and copper catalyst to form boric acid, formate salts, and organics (including benzene). This off-gas will be condensed and transferred to the organic Waste Storage Tank.

\begin{tabular}{|c|c|c|c|c|c|c|c|}
\hline \multicolumn{6}{|c|}{$\begin{array}{l}\text { Current Inventory as } \\
\text { of December 31, } 1991\end{array}$} & \multirow{2}{*}{\multicolumn{2}{|c|}{$\begin{array}{l}\text { PROJECTED } \\
\text { GENERATION } \\
1992 \text { THROUGH } \\
1996\end{array}$}} \\
\hline \multicolumn{2}{|c|}{$\begin{array}{l}\text { Not Subject To } \\
\text { LDR Prohibition }\end{array}$} & \multicolumn{2}{|c|}{$\begin{array}{l}\text { SUBJECT TO } \\
\text { LDR Prohibition }\end{array}$} & \multicolumn{2}{|c|}{ TOTAL } & & \\
\hline $\begin{array}{l}\text { Cubic } \\
\text { Meter }\end{array}$ & $\mathrm{kg}$ & $\begin{array}{l}\text { Cubic } \\
\text { Meter }\end{array}$ & $\mathrm{kg}$ & $\begin{array}{l}\text { Cubic } \\
\text { Meter }\end{array}$ & $\mathrm{kg}$ & $\begin{array}{l}\text { Cubic } \\
\text { Meter }\end{array}$ & $\mathrm{kg}$ \\
\hline 0.000 & 0.000 & 0.000 & 0.000 & 0.000 & 0.000 & 756.0 & $6.645 \mathrm{E} 5$ \\
\hline
\end{tabular}

Treatability Group:

MLLW $\mathrm{CH}$, Organic Liquids, Toxic organics and Metals w/ Mercury

Treatment status:

Plan to treat on-site at the planned consolidated Incinerati on Facility.

Technology status:

Technology exists. No modifications are necessary.

Radiation Characteristics:

1) Beta/gamma emitter

2) Contact-handled

Waste Specific Radiation Effects on Treatment:

1) None.

Waste Minimization Activitiies:

1) Not Applicable. 
State: South Carolina

ID \# :

884

Site: SAVANNAH RIVER SITE

Waste Stream Name: DWPF BENZENE

Matrix: Organic Liquids

Waste Type: MLLW

Waste has not yet been generated.

General Comments:

RCRA CODES

Waste Charcterization Basis: Process Knowledge

\begin{tabular}{|l|l|l|}
\hline Waste Codes & LDR Basis & Best Demonstrated Available Technologies \\
\hline D001A & Tech. & $\begin{array}{l}\text { Fuel Substitution; Organics Recovery; or I } \\
\text { ncineration }\end{array}$ \\
\hline D009C & Conc. & $\begin{array}{l}\text { Thermal Recovery of Metals; Acid Leaching; } \\
\text { Stabilization; or Incineration }\end{array}$ \\
\hline D018 & $\begin{array}{l}\text { Not currently prohibited under the LDR Prog } \\
\text { ram. }\end{array}$ \\
\hline
\end{tabular}


State: South Carolina

ID \# :

910

Site: SAVANNAH RIVER SITE

Waste Stream Name: SOLVENT WASTE <100 NCI/G TRU RAD

Matrix: Organic Debris

Waste Type: MLLW

Waste Stream Description and Source:

200 Areas ( $F$ and $H$ Separations Facilities). This waste is primarily solids consisting of mainly booties, lab coats, floor sweepings, and rags.

This waste is generated primarily through separation activities in the course of plutonium production, includes small amounts of TRU waste from on site laboratories.

\begin{tabular}{|c|c|c|c|c|c|c|c|}
\hline \multicolumn{6}{|c|}{$\begin{array}{l}\text { Current Inventory as } \\
\text { of December } 31,1991\end{array}$} & \multirow{2}{*}{\multicolumn{2}{|c|}{$\begin{array}{l}\text { PROJECTED } \\
\text { GENERATION } \\
1992 \text { THROUGH } \\
1996\end{array}$}} \\
\hline \multicolumn{2}{|c|}{$\begin{array}{l}\text { Not Subject To } \\
\text { LDR Prohibition }\end{array}$} & \multicolumn{2}{|c|}{$\begin{array}{l}\text { SUBJECT TO } \\
\text { LDR Prohibition }\end{array}$} & \multicolumn{2}{|c|}{ TOTAL } & & \\
\hline $\begin{array}{l}\text { Cubic } \\
\text { Meter }\end{array}$ & $\mathrm{kg}$ & $\begin{array}{l}\text { Cubic } \\
\text { Meter }\end{array}$ & $\mathrm{kg}$ & $\begin{array}{l}\text { Cubic } \\
\text { Meter }\end{array}$ & $\mathrm{kg}$ & $\begin{array}{l}\text { Cubic } \\
\text { Meter }\end{array}$ & $\mathrm{kg}$ \\
\hline $1.104 \mathrm{E} \cdot 3$ & $2.538 \mathrm{E} 5$ & $1.688 \mathrm{E} 3$ & $3.895 E \quad 5$ & $2.791 \mathrm{E} 3$ & $6.433 \mathrm{E} 5$ & 0.000 & 0.000 \\
\hline
\end{tabular}

Treatability Group:

MLLW CH/AL, Organic Debris, Toxic Organics and Metals w/ Mercury

Treatment status:

Have not identified a planned facility for this waste stream at this time.

No treatment identified.

Technology status:

Technology assessment has not started.

Radiation Characteristics:

1) Alpha emitter, 10-100 $\mathrm{nCi} / \mathrm{g}$

2) Contact-handled

3) Transuranic contaminants

Waste Specific Radiation Effects on Treatment:

1) Certain isotopes of U, Pu, Am, Cm, Cf, Np and Th are no n-accountable if present below specific levels, and req uire different levels of safeguards, depending on the a mount present. Treatments resulting in concentration o $f$ the material can result in the " 
State: South Carolina

ID \#:

910

Site: SAVANNAH RIVER SITE

Waste Stream Name: SOLVENT WASTE <100 NCI/G TRU RAD

Matrix: Organic Debris

Waste Type: MLLW

roll up" of large volumes of non-accountable wastes int o a smaller volume of accountable waste or change a mix ed low-level waste to a TRU waste.

2) Radioactive decay may produce significant amounts of he at that needs to be considered during treatment and dis posal.

Waste Minimization Activitiies:

1) Product change: product substitution and conservation; and change in product composition.

General Comments:

RCRA CODES

Waste Charcterization Basis: Process Knowledge

\begin{tabular}{|c|c|c|}
\hline Waste Codes & LDR Basis & Best Demonstrated Available Technologies \\
\hline D001A & Tech. & $\begin{array}{l}\text { Fuel Substitution; Organics Recovery; or I } \\
\text { ncineration }\end{array}$ \\
\hline D003D & Tech. & Deactivation \\
\hline D004 & Conc. & Vitrification \\
\hline D006B & Conc. & stabilization \\
\hline Do07 & conc. & $\begin{array}{l}\text { Chemical Reduction followed by stabilizatio } \\
n\end{array}$ \\
\hline Do08B & Conc. & stabilization \\
\hline Do09C & Conc. & $\begin{array}{l}\text { Thermal Recovery of Metals; Acid Leaching; } \\
\text { Stabilization; or Incineration }\end{array}$ \\
\hline D011 & Conc. & Stabilization \\
\hline D018 & & $\begin{array}{l}\text { Not currently prohibited under the LDR Prog } \\
\text { ram. }\end{array}$ \\
\hline D019 & & $\begin{array}{l}\text { Not currently prohibited under the LDR Prog } \\
\text { ram. }\end{array}$ \\
\hline $\mathrm{DO} 22$ & & $\begin{array}{l}\text { Not currently prohibited under the LDR Prog } \\
\text { ram. }\end{array}$ \\
\hline
\end{tabular}




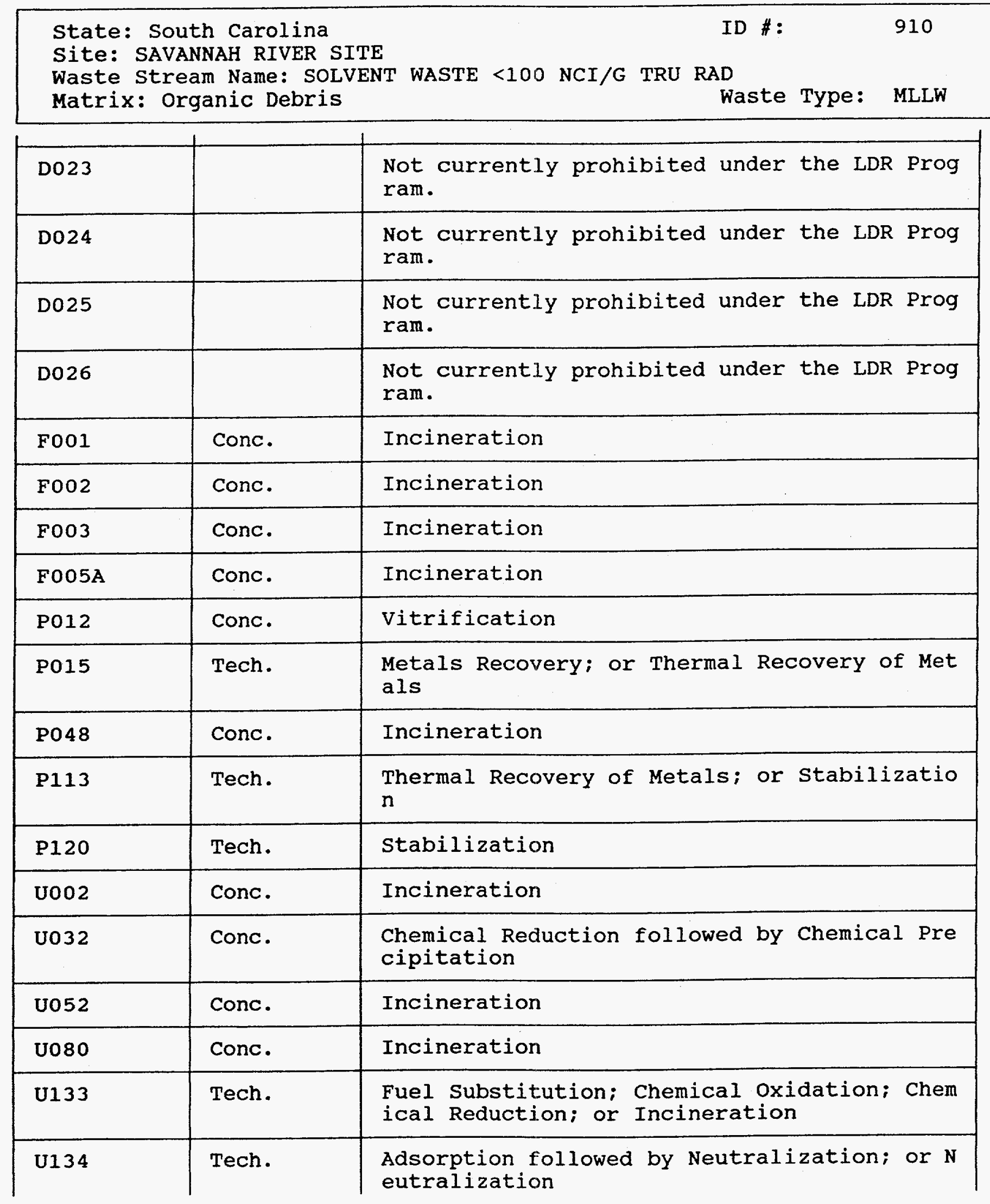


State: South Carolina

Site: SAVANNAH RIVER SITE

ID \# :

910

Waste Stream Name: SOLVENT WASTE <100 NCI/G TRU RAD

Matrix: Organic Debris

Waste Type: MLLW

\begin{tabular}{|l|l|l|}
\hline U144 & Conc. & Incineration followed by Stabilization \\
\hline U151 & Tech. & Amalgamation \\
\hline U154 & Tech. & Fuel Substitution; or Incineration \\
\hline U161 & Conc. & Incineration \\
\hline U209 & Conc. & Incineration \\
\hline U211 & Conc. & Incineration \\
\hline U220 & Conc. & Incineration \\
\hline U226 & Conc. & Incineration \\
\hline U239 & Conc. & Incineration \\
\hline
\end{tabular}

The alternate LDR treatment standards for debris is treatment prior to land disposal using any of the following technologies: extraction (physical , chemical or thermal), destruction(biological, chemical, or thermal), macro/microencapsulation or sealing. 
State: Washington

ID \# :

932

Site: HANFORD SITE

Waste Stream Name: TC METAL ORGANIC SOLID DEBRIS

Matrix: Heterogeneous Debris

Waste Type: MLLW

Waste Stream Description and Source:

Hanford Treatability Group Identification Number: 90-LLMW-13

18IC (HANF - 13) Waste generated from cleanup and

maintenance activities of various process and support

operations. Waste consists of adsorbed organic chemicals

and various organic debris. Waste stream is contaminated

solid debris (mostly organic debris). Contaminants consist of some ignitables, corrosives, and TC metals.

\begin{tabular}{|c|c|c|c|c|c|c|c|}
\hline \multicolumn{6}{|c|}{$\begin{array}{l}\text { Current Inventory as } \\
\text { of December } 31,1991\end{array}$} & \multirow{2}{*}{\multicolumn{2}{|c|}{$\begin{array}{l}\text { PROJECTED } \\
\text { GENERATION } \\
1991 \text { THROUGH } \\
1997\end{array}$}} \\
\hline \multicolumn{2}{|c|}{$\begin{array}{l}\text { Not Subject To } \\
\text { LDR Prohibition }\end{array}$} & \multicolumn{2}{|c|}{$\begin{array}{l}\text { SUBJECT TO } \\
\text { LDR Prohibition }\end{array}$} & \multicolumn{2}{|c|}{ TOTAL } & & \\
\hline $\begin{array}{l}\text { Cubic } \\
\text { Meter }\end{array}$ & $\mathrm{kg}$ & $\begin{array}{l}\text { Cubic } \\
\text { Meter }\end{array}$ & $\mathrm{kg}$ & $\begin{array}{l}\text { Cubic } \\
\text { Meter }\end{array}$ & $\mathrm{kg}$ & $\begin{array}{l}\text { Cubic } \\
\text { Meter }\end{array}$ & $\mathrm{kg}$ \\
\hline 0.000 & 0.000 & 23.90 & $2.392 \mathrm{E} \quad 4$ & 23.90 & $2.392 \mathrm{E} \quad 4$ & 15.80 & $1.578 \mathrm{E} \quad 4$ \\
\hline
\end{tabular}

Treatability Group:

MLLW CH/AL, Heterogeneous Debris, Toxic Organics and Metals

w/o Mercury

Treatment status:

Have not identified a planned facility for this waste stream at this time.

Technology status:

Technology exists. Needs modifications or verification for application to DOE waste streams.

Radiation Characteristics:

1) Contact-handled

2) Alpha emitter, 10-100 nCi/g

3) Activation Products

4) Beta/gamma emitter

5) Volatile radionuclide

Waste Specific Radiation Effects on Treatment:

1) Daughter products of alpha emitters may cause problems, 
State: Washington

Site: HANFORD SITE

Waste stream Name: TC METAL ORGANIC SOLID DEBRIS

Matrix: Heterogeneous Debris

ID \#:

932

i.e., production of radon gas, emissions from short-1i ved daughter products, and potential chemical incompati bility of daughter products.

2) Many activation products are short-lived and treatment could be delayed to allow radiation levels to subside.

3) High beta or gamma levels in contact with organics can result in radiolysis, with production of hydrogen gas a nd formation of free radicals that attack structural ma terials, particularly steel. The buildup of hydrogen $g$. as and embrittlement of structural

materials are important considerations, in storage, de sign, and operation of treatment facilities, and in sta bilization of the final waste form.

4) Treatment must consider radioactive off-gases to protec $t$ the public and treatment facility personnel from rele ases.

Waste Minimization Activitiies:

1) Improved operating practices: changes in material handl ing and inventory procedures; waste segregation; and changes in production scheduling.

2) Product change: product substitution and conservation; and change in product composition.

General Comments:

on an average $>90 \%$ have beta-gamma emitters, $30 \%$ to $50 \%$

alpha and activation products, and a small but significant fraction with volatile radionuclides.

RCRA CODES

Waste Charcterization Basis: Sampling Analysis

\begin{tabular}{|c|c|c|}
\hline Waste Codes & LDR Basis & Best Demonstrated Available Technologies \\
\hline Do01F & Tech. & Deactivation \\
\hline $\mathrm{DO02B}$ & Tech. & Deactivation \\
\hline D005 & Conc. & Chemical Precipitation; or stabilization \\
\hline D006B & Conc. & stabilization \\
\hline D007 & Conc. & $\begin{array}{l}\text { Chemical Reduction followed by stabilizatio } \\
\mathrm{n}\end{array}$ \\
\hline
\end{tabular}


State: Washington

ID \#:

932

Site: HANFORD SITE

Waste stream Name: TC METAL ORGANIC SOLID DEBRIS

Matrix: Heterogeneous Debris

Waste Type: MLLW

\begin{tabular}{|l|l|l|}
\hline D008B & Conc. & Stabilization \\
\hline D010 & Conc. & Stabilization \\
\hline D035 & $\begin{array}{l}\text { Not currently prohibited under the LDR Prog } \\
\text { ram. }\end{array}$ \\
\hline
\end{tabular}

The alternate LDR treatment standards for debris is treatment prior to land disposal using any of the following technologies: extraction (physical , chemical or thermal), destruction(biological, chemical, or thermal), macro/microencapsulation or sealing. 
State: Washington

ID \# :

933

Site: HANFORD SITE

Waste Stream Name: TC METAL ORGANIC SOLID DEBRIS (CA)

Matrix: Heterogeneous Debris

Waste Type: MLLW

Waste Stream Description and Source:

Hanford Treatability Group Identification Number:

90-LLMW-14; 18CA (HANF - 14) Waste generated from cleanup and maintenance activities of various process and support operations. Waste consists of adsorbed organic chemicals and various organic debris. The assumption used to categorizing as California List waste was the washington State identified codes WPO1 and WPO2 (identifying halogenated hydrocarbons). Waste stream is contaminated solid debris (mostly organic debris). Contaminants consist mostly TC metals and low concentrations of halogenated hydrocarbons.

\begin{tabular}{|c|c|c|c|c|c|c|c|}
\hline \multicolumn{6}{|c|}{$\begin{array}{l}\text { Current Inventory as } \\
\text { of December } 31,1991\end{array}$} & \multirow{2}{*}{\multicolumn{2}{|c|}{$\begin{array}{l}\text { PROJECTED } \\
\text { GENERATION } \\
1991 \text { THROUGH } \\
1997\end{array}$}} \\
\hline \multicolumn{2}{|c|}{$\begin{array}{l}\text { Not Subject To } \\
\text { LDR Prohibition }\end{array}$} & \multicolumn{2}{|c|}{$\begin{array}{l}\text { SUBJECT TO } \\
\text { LDR Prohibition }\end{array}$} & \multicolumn{2}{|c|}{ TOTAL } & & \\
\hline $\begin{array}{l}\text { Cubic } \\
\text { Meter }\end{array}$ & $\mathrm{kg}$ & $\begin{array}{l}\text { Cubic } \\
\text { Meter }\end{array}$ & $\mathrm{kg}$ & $\begin{array}{l}\text { Cubic } \\
\text { Meter }\end{array}$ & $\mathrm{kg}$ & $\begin{array}{l}\text { Cubic } \\
\text { Meter }\end{array}$ & $\mathrm{kg}$ \\
\hline 0.000 & 0.000 & 11.30 & $1.128 \mathrm{E} \quad 4$ & 11.30 & $1.128 \mathrm{E} 4$ & 7.400 & $7.440 \mathrm{E} 3$ \\
\hline
\end{tabular}

Treatability Group:

MLIW CH/AL, Heterogeneous Debris, Toxic Metals w/o Mercury

Treatment status:

Have not identified a planned facility for this waste stream at this time.

Technology status:

Technology exists. Needs modifications or verification for application to DOE waste streams.

Radiation Characteristics:

1) Contact-handled

2) Alpha emitter, 10-100 $\mathrm{nCi} / \mathrm{g}$

3) Activation Products

4) Beta/gamma emitter

5) Volatile radionuclide 
State: Washington

Site: HANFORD SITE

ID \# :

933

Waste stream Name: TC METAL ORGANIC SOLID DEBRIS (CA)

Matrix: Heterogeneous Debris

Waste Type: MLLW

Waste Specific Radiation Effects on Treatment:

1) Daughter products of alpha emitters may cause problems, i.e., production of radon gas, emissions from short-li ved daughter products, and potential chemical incompati bility of daughter products.

2) Many activation products are short-lived and treatment could be delayed to allow radiation levels to subside.

3) High beta or gamma levels in contact with organics can result in radiolysis, with production of hydrogen gas a nd formation of free radicals that attack structural ma terials, particularly steel. The buildup of hydrogen $g$ as and embrittlement of structural

materials are important considerations, in storage, de sign, and operation of treatment facilities, and in sta bilization of the final waste form.

4) Treatment must consider radioactive off-gases to protec $t$ the public and treatment facility personnel from rele ases.

Waste Minimization Activitiies:

1) Improved operating practices: changes in material handl ing and inventory procedures; waste segregation; and changes in production scheduling.

2) Product change: product substitution and conservation; and change in product composition.

General Comments:

On an average $>90 \%$ have beta-gamma emitters, $30 \%$ to $50 \%$ alpha and activation products, and a small but significant fraction with volatile radionuclides.

RCRA CODES

Waste Charcterization Basis: Sampling Analysis

\begin{tabular}{|c|c|c|}
\hline Waste Codes & LDR Basis & Best Demonstrated Available Technologies \\
\hline D005 & Conc. & Chemical Precipitation; or stabilization \\
\hline D006B & Conc. & stabilization \\
\hline D007 & Conc. & $\begin{array}{l}\text { Chemical Reduction followed by stabilizatio } \\
\mathrm{n}\end{array}$ \\
\hline
\end{tabular}

$05 / 17 / 94$ 
State: Washington

ID \# :

933

Site: HANFORD SITE

Waste stream Name: TC METAL ORGANIC SOLID DEBRIS (CA)

Matrix: Heterogeneous Debris

Waste Type: MLLW

\begin{tabular}{|l|l|l|}
\hline D008B & Conc. & Stabilization \\
\hline D010 & Conc. & Stabilization \\
\hline
\end{tabular}

The alternate LDR treatment standards for debris is treatment prior to land disposal using any of the following technologies: extraction (physical - chemical or thermal), destruction(biological, chemical, or thermal), macro/microencapsulation or sealing. 
State: Washington

ID \# :

945

Site: HANFORD SITE

Waste Stream Name: NON-TC METAL/SOLVENT ORG. SOLID DEBRIS

Matrix: Heterogeneous Debris

Waste Type: MLLW

Waste Stream Description and Source:

Hanford Treatability Group Identification Number:

90-LLMW-17; 18NICR (HANF - 17) Waste generated from

cleanup and maintenance activities of various process and

support operation. Waste consists of adsorbed organic chemicals and various organic debris. Waste stream is contaminated soild debris (mostly organic debris). Waste constituents consist of absorbents, soil, plastics, and cellulose materials.

\begin{tabular}{|c|c|c|c|c|c|c|c|}
\hline \multicolumn{6}{|c|}{$\begin{array}{l}\text { Current Inventory as } \\
\text { of December } 31,1991\end{array}$} & \multirow{2}{*}{\multicolumn{2}{|c|}{$\begin{array}{l}\text { PROJECTED } \\
\text { GENERATION } \\
1991 \text { THROUGH } \\
1997\end{array}$}} \\
\hline \multicolumn{2}{|c|}{$\begin{array}{l}\text { Not Subject To } \\
\text { LDR Prohibition }\end{array}$} & \multicolumn{2}{|c|}{$\begin{array}{l}\text { SUBJECT TO } \\
\text { LDR Prohibition }\end{array}$} & \multicolumn{2}{|c|}{ TOTAL } & & \\
\hline $\begin{array}{l}\text { Cubic } \\
\text { Meter }\end{array}$ & $\mathrm{kg}$ & $\begin{array}{l}\text { Cubic } \\
\text { Meter }\end{array}$ & $\mathrm{kg}$ & $\begin{array}{l}\text { Cubic } \\
\text { Meter }\end{array}$ & $\mathrm{kg}$ & $\begin{array}{l}\text { Cubic } \\
\text { Meter }\end{array}$ & $\mathrm{kg}$ \\
\hline 0.000 & 0.000 & 9.900 & $9.940 \mathrm{E} 3$ & 9.900 & $9.940 \mathrm{E} 3$ & 6.600 & $6.560 \mathrm{E} 3$ \\
\hline
\end{tabular}

Treatability Group:

MLLW CH/AL, Heterogeneous Debris, Toxic Organics

Treatment status:

Have not identified a planned facility for this waste stream at this time.

Technology status:

Technology exists. Needs modifications or verification for application to DOE waste streams.

Radiation Characteristics:

1) Contact-handled

2) Alpha emitter, 10-100 nCi/g

3) Activation Products

4) Beta/gamma emitter

5) Volatile radionuclide

Waste Specific Radiation Effects on Treatment:

1) Daughter products of alpha emitters may cause problems, 
State: Washington

Site: HANFORD SITE

ID \# :

945

Waste Stream Name: NON-TC METAL/SOLVENT ORG. SOLID DEBRIS

Matrix: Heterogeneous Debris

Waste Type: MLLW

i.e., production of radon gas, emissions from short-li ved daughter products, and potential chemical incompati bility of daughter products.

2) Many activation products are short-lived and treatment could be delayed to allow radiation levels to subside.

3) High beta or gamma levels in contact with organics can result in radiolysis, with production of hydrogen gas a nd formation of free radicals that attack structural ma terials, particularly steel. The buildup of hydrogen $g$ as and embrittlement of structural

materials are important considerations, in storage, de sign, and operation of treatment facilities, and in sta bilization of the final waste form.

4) Treatment must consider radioactive off-gases to protec $t$ the public and treatment facility personnel from rele ases.

Waste Minimization Activitiies:

1) Product change: product substitution and conservation; and change in product composition.

General Comments:

on an average $>90 \%$ have beta-gamma emitters, $30 \%$ to $50 \%$

alpha and activation products, and a small but significant

fraction with volatile radionuclides.

RCRA CODES

Waste Charcterization Basis: Sampling Analysis

\begin{tabular}{|c|c|c|}
\hline Waste Codes & LDR Basis & Best Demonstrated Available Technologies \\
\hline D001E & Tech. & Deactivation \\
\hline $\mathrm{D} 001 \mathrm{~F}$ & Tech. & Deactivation \\
\hline D002A & Tech. & Deactivation \\
\hline $\mathrm{DOO2B}$ & Tech. & Deactivation \\
\hline $\mathrm{DO03E}$ & Tech. & Deactivation \\
\hline D018 & & $\begin{array}{l}\text { Not currently prohibited under the LDR Prog } \\
\text { ram. }\end{array}$ \\
\hline
\end{tabular}

$05 / 17 / 94$ 
State: Washington

ID \#:

945

Site: HANFORD SITE

Waste Stream Name: NON-TC METAL/SOLVENT ORG. SOLID DEBRIS

Matrix: Heterogeneous Debris

Waste Type: MLLW

1

The alternate LDR treatment standards for debris is treatment prior to land disposal using any of the following technologies: extraction (physical - chemical or thermal), destruction(biological, chemical, or thermal), macro/microencapsulation or sealing. 
State: Ohio

ID \#: 0000010029

Site: FERNALD ENVIRONMENTAL MANAGEMENT PROJECT

Waste Stream Name: CONTAMINATED INSOLUBLE OIL

Matrix: Organic Liquids

Waste Type: MLLW

Waste Stream Description and Source:

Contaminated insoluble oil; 921 Plant 9, Casting, $\mathrm{N}-\mathrm{R}$

Furnace.

\begin{tabular}{|c|c|c|c|c|c|c|c|}
\hline \multicolumn{6}{|c|}{$\begin{array}{l}\text { Current Inventory as } \\
\text { of December } 31,1992\end{array}$} & \multirow{2}{*}{\multicolumn{2}{|c|}{$\begin{array}{l}\text { PROJECTED } \\
\text { GENERATION } \\
1993 \text { THROUGH } \\
1997\end{array}$}} \\
\hline \multicolumn{2}{|c|}{$\begin{array}{l}\text { Not Subject To } \\
\text { LDR Prohibition }\end{array}$} & \multicolumn{2}{|c|}{$\begin{array}{l}\text { SUBJECT TO } \\
\text { LDR Prohibition }\end{array}$} & \multicolumn{2}{|c|}{ TOTAL } & & \\
\hline $\begin{array}{l}\text { Cubic } \\
\text { Meter }\end{array}$ & $\mathrm{kg}$ & $\begin{array}{l}\text { Cubic } \\
\text { Meter }\end{array}$ & $\mathrm{kg}$ & $\begin{array}{l}\text { Cubic } \\
\text { Meter }\end{array}$ & $\mathrm{kg}$ & $\begin{array}{l}\text { Cubic } \\
\text { Meter }\end{array}$ & $\mathrm{kg}$ \\
\hline 0.000 & 0.000 & 1.700 & $1.389 \mathrm{E} \quad 3$ & 1.700 & $1.389 \mathrm{E} \quad 3$ & 0.000 & 0.000 \\
\hline
\end{tabular}

Treatability Group:

MLLW $\mathrm{CH}$, Organic Liquids, Toxic Organics and Metals $w / 0$ Mercury

Treatment status:

Have not identified a planned facility for this waste stream at this time.

All waste streams are being evaluated for appropriate

treatment under CERCLA.

Technology status:

Technology exists. Needs modifications or verification for application to DOE waste streams.

Radiation Characteristics:

1) Contact-handled

Waste Specific Radiation Effects on Treatment:

1) Certain isotopes of $\mathrm{U}, \mathrm{Pu}, \mathrm{Am}, \mathrm{Cm}, \mathrm{Cf}, \mathrm{Np}$ and $\mathrm{Th}$ are no n-accountable if present below specific levels, and req uire different levels of safeguards, depending on the a mount present. Treatments resulting in concentration 0 $f$ the material can result in the " roll up" of large volumes of non-accountable wastes int - a smaller volume of accountable waste or change a mix ed low-level waste to a TRU waste. 
State: Ohio

Site: FERNALD ENVIRONMENTAL MANAGEMENT PROJECT

ID \# : 0000010029

Waste stream Name: CONTAMINATED INSOLUBLE OIL

Matrix: Organic Liquids

Waste Type: MLLW

Waste Minimization Activitiies:

1) Not Applicable.

The waste stream is no longer being generated.

General Comments:

RCRA CODES

Waste Charcterization Basis: Sampling Analysis

\begin{tabular}{|l|l|l|}
\hline Waste Codes & LDR Basis & Best Demonstrated Available Technologies \\
\hline D006B & Conc. & Stabilization \\
\hline D007 & Conc. & $\begin{array}{l}\text { Chemical Reduction followed by Stabilizatio } \\
\mathrm{n}\end{array}$ \\
\hline D008C & Tech. & Macroencapsulation \\
\hline D019 & & $\begin{array}{l}\text { Not currently prohibited under the LDR Prog } \\
\text { ram }\end{array}$ \\
\hline D029 & $\begin{array}{l}\text { Not currently prohibited under the LDR Prog } \\
\text { ram. }\end{array}$ \\
\hline D040 & $\begin{array}{l}\text { Not currently prohibited under the LDR Prog } \\
\text { ram. }\end{array}$ \\
\hline F001 & Conc. & \begin{tabular}{l} 
Incineration \\
\hline
\end{tabular}
\end{tabular}


State: Ohio

Site: FERNALD ENVIRONMENTAL MANAGEMENT PROJECT

Waste stream Name: CONTAMINATED OIL, INSOLUBLE

Matrix: Organic Liquids
ID \#: 0000010027

Waste Type: MLLW

Waste Stream Description and Source:

Contaminated oil, insoluble; 600 Plant 6, General.

\begin{tabular}{|c|c|c|c|c|c|c|c|}
\hline \multicolumn{6}{|c|}{$\begin{array}{l}\text { Current Inventory as } \\
\text { of December } 31,1992\end{array}$} & \multirow{2}{*}{\multicolumn{2}{|c|}{$\begin{array}{l}\text { PROJECTED } \\
\text { GENERATION } \\
1993 \text { THROUGH } \\
1997\end{array}$}} \\
\hline \multicolumn{2}{|c|}{$\begin{array}{l}\text { Not Subject To } \\
\text { LDR Prohibition }\end{array}$} & \multicolumn{2}{|c|}{$\begin{array}{l}\text { SUBJECT TO } \\
\text { LDR Prohibition }\end{array}$} & \multicolumn{2}{|c|}{ TOTAL } & & \\
\hline $\begin{array}{l}\text { Cubic } \\
\text { Meter }\end{array}$ & $\mathrm{kg}$ & $\begin{array}{l}\text { Cubic } \\
\text { Meter }\end{array}$ & $\mathrm{kg}$ & $\begin{array}{l}\text { Cubic } \\
\text { Meter }\end{array}$ & $\mathrm{kg}$ & $\begin{array}{l}\text { Cubic } \\
\text { Meter }\end{array}$ & $\mathrm{kg}$ \\
\hline 0.000 & 0.000 & 2.900 & $2.507 \mathrm{E} 3$ & 2.900 & $2.507 \mathrm{E} 3$ & 0.000 & 0.000 \\
\hline
\end{tabular}

Treatability Group:

MLLW $\mathrm{CH}$, Organic Liquids, Toxic organics

Treatment status:

Have not identified a planned facility for this waste stream at this time.

All waste streams are being evaluated for appropriate

treatment under CERCLA.

Technology status:

Technology exists. Needs modifications or verification for

application to DOE waste streams.

Radiation Characteristics:

1) Contact-handled

Waste Specific Radiation Effects on Treatment:

1) Certain isotopes of U, $\mathrm{Pu}, \mathrm{Am}, \mathrm{Cm}, \mathrm{Cf}, \mathrm{Np}$ and $\mathrm{Th}$ are no n-accountable if present below specific levels, and req uire different levels of safeguards, depending on the a mount present. Treatments resulting in concentration o $f$ the material can result in the "

roll up" of large volumes of non-accountable wastes int - a smaller volume of accountable waste or change a mix ed low-level waste to a TRU waste.

Waste Minimization Activitiies:

1) Not Applicable. 
State: Ohio

ID \#: 0000010027

Site: FERNALD ENVIRONMENTAL MANAGEMENT PROJECT

Waste stream Name: CONTAMINATED OIL, INSOLUBLE

Matrix: Organic Liquids

Waste Type: MLLW

The waste stream is no longer being generated.

General Comments:

RCRA CODES

Waste Charcterization Basis: Sampling Analysis

\begin{tabular}{|l|l|l|}
\hline Waste Codes & LDR Basis & Best Demonstrated Available Technologies \\
\hline D039 & $\begin{array}{l}\text { Not currently prohibited under the LDR Prog } \\
\text { ram. }\end{array}$ \\
\hline D040 & $\begin{array}{l}\text { Not currently prohibited under the LDR Prog } \\
\text { ram. }\end{array}$ \\
\hline F001 & Conc. & Incineration \\
\hline
\end{tabular}


State: Ohio

ID \#: 0000060119

Site: FERNALD ENVIRONMENTAL MANAGEMENT PROJECT

Waste stream Name: SLUDGES, OILY, FOR OXIDATION HIGH FREE

Matrix: Organic Sludges/Particulates

Waste Type: MLLW

Waste Stream Description and Source:

Sludges, oily, for oxidation high free metal; 741

Procurement, Garage.

\begin{tabular}{|c|c|c|c|c|c|c|c|}
\hline \multicolumn{6}{|c|}{$\begin{array}{l}\text { Current Inventory as } \\
\text { of December } 31,1992\end{array}$} & \multirow{2}{*}{\multicolumn{2}{|c|}{$\begin{array}{l}\text { PROJECTED } \\
\text { GENERATION } \\
1993 \text { THROUGH } \\
1997\end{array}$}} \\
\hline \multicolumn{2}{|c|}{$\begin{array}{l}\text { Not Subject To } \\
\text { LDR Prohibition }\end{array}$} & \multicolumn{2}{|c|}{$\begin{array}{l}\text { SUBJECT TO } \\
\text { LDR Prohibition }\end{array}$} & \multicolumn{2}{|c|}{ TOTAL } & & \\
\hline $\begin{array}{l}\text { Cubic } \\
\text { Meter }\end{array}$ & $\mathrm{kg}$ & $\begin{array}{l}\text { Cubic } \\
\text { Meter }\end{array}$ & $\mathrm{kg}$ & $\begin{array}{l}\text { Cubic } \\
\text { Meter }\end{array}$ & $\mathrm{kg}$ & $\begin{array}{l}\text { Cubic } \\
\text { Meter }\end{array}$ & $\mathrm{kg}$ \\
\hline 0.000 & 0.000 & 3.300 & $2.972 \mathrm{E} 3$ & 3.300 & $2.972 \mathrm{E} \quad 3$ & 0.000 & 0.000 \\
\hline
\end{tabular}

Treatability Group:

MLLW CH, Organic Sludges/Particulates, Toxic Organics

Treatment status:

Have not identified a planned facility for this waste stream at this time.

All waste streams are being evaluated for appropriate treatment under CERCLA.

Technology status:

Technology exists. Needs modifications or verification for application to DOE waste streams.

Radiation Characteristics:

1) Contact-handled

Waste Specific Radiation Effects on Treatment:

1) Certain isotopes of $\mathrm{U}, \mathrm{Pu}, \mathrm{Am}, \mathrm{Cm}, \mathrm{Cf}, \mathrm{Np}$ and $\mathrm{Th}$ are no n-accountable if present below specific levels, and req uire different levels of safeguards, depending on the a mount present. Treatments resulting in concentration 0 $f$ the material can result in the " roll up" of large volumes of non-accountable wastes int o a smaller volume of accountable waste or change a mix ed low-level waste to a TRU waste.

Waste Minimization Activitiies:

1) Not Applicable. 
State: Ohio

ID \# : 0000060119

Site: FERNALD ENVIRONMENTAL MANAGEMENT PROJECT

Waste stream Name: SLUDGES, OILY, FOR OXIDATION HIGH FREE

Matrix: Organic Sludges/Particulates

Waste Type: MLLW

The waste stream is no longer being generated.

General Comments:

RCRA CODES

Waste Charcterization Basis: Sampling Analysis

\begin{tabular}{|l|l|l|}
\hline Waste Codes & LDR Basis & Best Demonstrated Available Technologies \\
\hline D001A & Tech. & $\begin{array}{l}\text { Fuel Substitution; Organics Recovery; or I } \\
\text { ncineration }\end{array}$ \\
\hline F001 & Conc. & Incineration \\
\hline F002 & Conc. & Incineration \\
\hline
\end{tabular}


State: Idaho

Site: IDAHO NATIONAL ENGINEERING LABORATORY

Waste stream Name: TAN DECON SOLVENTS WASTES

Matrix: Organic Liquids
ID \#: ID-EGG-162

Waste Type: MLLW

Waste Stream Description and Source:

Decontamination and decommissioning of a decontamination facility. Waste stream generated from maintenance. This waste is no longer generated.

\begin{tabular}{|c|c|c|c|c|c|c|c|}
\hline \multicolumn{6}{|c|}{$\begin{array}{l}\text { Current Inventory as } \\
\text { of December } 31,1992\end{array}$} & \multirow{2}{*}{\multicolumn{2}{|c|}{$\begin{array}{l}\text { PROJECTED } \\
\text { GENERATION } \\
1993 \text { THROUGH } \\
1997\end{array}$}} \\
\hline \multicolumn{2}{|c|}{$\begin{array}{l}\text { Not Subject To } \\
\text { LDR Prohibition }\end{array}$} & \multicolumn{2}{|c|}{$\begin{array}{l}\text { SUBJECT TO } \\
\text { LDR Prohibition }\end{array}$} & \multicolumn{2}{|c|}{ TOTAL } & & \\
\hline $\begin{array}{l}\text { Cubic } \\
\text { Meter }\end{array}$ & $\mathrm{kg}$ & $\begin{array}{l}\text { Cubic } \\
\text { Meter }\end{array}$ & $\mathrm{kg}$ & $\begin{array}{l}\text { Cubic } \\
\text { Meter }\end{array}$ & $\mathrm{kg}$ & $\begin{array}{l}\text { Cubic } \\
\text { Meter }\end{array}$ & $\mathrm{kg}$ \\
\hline 0.000 & 0.000 & 5.900 & $5.937 \mathrm{E} 3$ & 5.900 & $5.937 \mathrm{E} 3$ & 0.000 & 0.000 \\
\hline
\end{tabular}

Treatability Group:

MLLW $\mathrm{CH}$, Organic Liquids, Toxic Organics and Metals w/

Mercury. The INEL has not completed an adequate evaluation

of the described chemical and hazardous matrix to identify a specific treatability group.

Treatment status:

Plan to treat on-site at the existing WERF Incinerator facil

ity.

Recommended treatments do not require significant

devlopment.

Technology status:

Technology exists. No modifications are necessary.

Radiation Characteristics:

1) Contact-handled

2) Beta/gamma emitter

3) Activation Products

Waste Specific Radiation Effects on Treatment:

1) Unknown.

Waste Minimization Activitiies: 
State: Idaho

Site: IDAHO NATIONAL ENGINEERING LABORATORY

Waste stream Name: TAN DECON SOLVENTS WASTES

Matrix: Organic Liquids

Change in operations status.

This waste stream is no longer generated.
ID \# : ID-EGG-162

Waste Type: MLLW

General Comments:

RCRA CODES

Waste Charcterization Basis: Process Knowledge

\begin{tabular}{|l|l|l|}
\hline Waste Codes & LDR Basis & Best Demonstrated Available Technologies \\
\hline D002B & Tech. & Deactivation \\
\hline D004 & Conc. & Vitrification \\
\hline D006B & Conc. & Stabilization \\
\hline D007 & Conc. & $\begin{array}{l}\text { Chemical Reduction followed by Stabilizatio } \\
\text { n }\end{array}$ \\
\hline D008B & Conc. & Stabilization \\
\hline D009C & Conc. & $\begin{array}{l}\text { Thermal Recovery of Metals; Acid Leaching; } \\
\text { Stabilization; or Incineration }\end{array}$ \\
\hline D010 & Conc. & Stabilization \\
\hline F001 & Conc. & Incineration \\
\hline F002 & Conc. & Incineration \\
\hline F003 & Conc. & Incineration \\
\hline F005A & Conc. & Incineration \\
\hline
\end{tabular}


State: Idaho

Site: IDAHO NATIONAL ENGINEERING LABORATORY

Waste Stream Name: SCRUB PUMP RADIOACTIVE OIL

Matrix: Organic Liquids

ID \#: ID-WIN-217

Waste Type: MLLW

Waste Stream Description and Source:

30 weight motor oil with trace amounts of heavy metals and Cs-137. Waste stream generated from production. Amount in storage is based upon information provided by material management. There are currently six/55 gallon drums. The calculated volume is based on 0.21 cubic meters/55 gallon drum $[55$ gallon* $(3.785 * 10 \mathrm{E}-3)=0.21$ cubic meters].

\begin{tabular}{|c|c|c|c|c|c|c|c|}
\hline & & $\begin{array}{l}\text { irrent } \\
\text { Dece }\end{array}$ & $\begin{array}{l}\text { ventory } \\
\mathrm{r} 31,1 \mathrm{~s}\end{array}$ & & & \multirow{2}{*}{\multicolumn{2}{|c|}{$\begin{array}{l}\text { PROJECTED } \\
\text { GENERATION } \\
1993 \text { THROUGH } \\
1997\end{array}$}} \\
\hline \multicolumn{2}{|c|}{$\begin{array}{l}\text { Not Subject To } \\
\text { LDR Prohibition }\end{array}$} & \multicolumn{2}{|c|}{$\begin{array}{l}\text { SUBJECT TO } \\
\text { LDR Prohibition }\end{array}$} & \multicolumn{2}{|c|}{ TOTAL } & & \\
\hline $\begin{array}{l}\text { Cubic } \\
\text { Meter }\end{array}$ & $\mathrm{kg}$ & $\begin{array}{l}\text { Cubic } \\
\text { Meter }\end{array}$ & $\mathrm{kg}$ & $\begin{array}{l}\text { Cubic } \\
\text { Meter }\end{array}$ & $\mathrm{kg}$ & $\begin{array}{l}\text { Cubic } \\
\text { Meter }\end{array}$ & $\mathrm{kg}$ \\
\hline 1.300 & $1.200 E 3$ & 0.000 & 0.000 & 1.300 & $1.200 \mathrm{E} 3$ & 0.740 & 711.0 \\
\hline
\end{tabular}

Treatability Group:

MLIW $\mathrm{CH}$, Organic Liquids, Toxic Metals w/o Mercury. The

INEL has not completed an adequate evaluation of the described chemical and hazardous matrix to identify a specific treatability group.

Treatment status:

Plan to treat on-site at the existing WERF Incinerator facil ity.

Incineration followed by grouting at WERF.

Technology status:

Technology exists. No modifications are necessary.

Radiation Characteristics:

1) Contact-handled

Waste Specific Radiation Effects on Treatment:

1) None.

Waste Minimization Activitiies:

1)

$05 / 17 / 94$ 
State: Idaho

Site: IDAHO NATIONAL ENGINEERING LABORATORY

ID \#: ID-WIN-217

waste stream Name: SCRUB PUMP RADIOACTIVE OIL

Matrix: Organic Liquids

Waste Type: MLLW

Good operating Practices.

General Comments:

RCRA CODES

Waste Charcterization Basis: Sampling Analysis

\begin{tabular}{|l|l|l|}
\hline Waste Codes & LDR Basis & Best Demonstrated Available Technologies \\
\hline D007 & Conc. & $\begin{array}{l}\text { Chemical Reduction followed by Stabilizatio } \\
\mathrm{n}\end{array}$ \\
\hline D008B & Conc. & Stabilization \\
\hline
\end{tabular}

$05 / 17 / 94$ 
State: Idaho

ID \#: ID-EGG-217

Site: IDAHO NATIONAL ENGINEERING LABORATORY

Waste stream Name: HEAVY METAL RADIOACTIVE OIL

Matrix: Organic Liquids

Waste Type: MLLW

Waste Stream Description and Source:

This waste is the result of maintenance activities. Waste stream generated from maintenance. This waste is no longer generated.

\begin{tabular}{|c|c|c|c|c|c|c|c|}
\hline \multicolumn{6}{|c|}{$\begin{array}{l}\text { Current Inventory as } \\
\text { of December } 31,1992\end{array}$} & \multirow{2}{*}{\multicolumn{2}{|c|}{$\begin{array}{l}\text { PROJECTED } \\
\text { GENERATION } \\
1993 \text { THROUGH } \\
1997\end{array}$}} \\
\hline \multicolumn{2}{|c|}{$\begin{array}{l}\text { Not Subject To } \\
\text { LDR Prohibition }\end{array}$} & \multicolumn{2}{|c|}{$\begin{array}{l}\text { SUBJECT TO } \\
\text { LDR Prohibition }\end{array}$} & \multicolumn{2}{|c|}{ TOTAL } & & \\
\hline $\begin{array}{l}\text { Cubic } \\
\text { Meter }\end{array}$ & $\mathrm{kg}$ & $\begin{array}{l}\text { Cubic } \\
\text { Meter }\end{array}$ & $\mathrm{kg}$ & $\begin{array}{l}\text { Cubic } \\
\text { Meter }\end{array}$ & $\mathrm{kg}$ & $\begin{array}{l}\text { Cubic } \\
\text { Meter }\end{array}$ & $\mathrm{kg}$ \\
\hline 1.700 & 796.5 & 0.000 & 0.000 & 1.700 & 796.5 & 0.000 & 0.000 \\
\hline
\end{tabular}

Treatability Group:

MLLW $\mathrm{CH}$, Organic Liquids, Toxic Metals w/o Mercury. The

INEL has not completed an adequate evaluation of the described chemical and hazardous matrix to identify a specific treatability group.

Treatment status:

Plan to treat on-site at the existing WERF Incinerator facil ity.

The treatment strategy does not require technology development.

Technology status:

Technology exists. No modifications are necessary.

Radiation Characteristics:

1) Contact-handled

2) Beta/gamma emitter

3) Activation Products

Waste Specific Radiation Effects on Treatment:

1) Unknown.

Waste Minimization Activitiies:

$05 / 17 / 94$ 
State: Idaho

ID \#: ID-EGG-217

Site: IDAHO NATIONAL ENGINEERING LABORATORY

Waste Stream Name: HEAVY METAL RADIOACTIVE OIL

Matrix: Organic Liquids

Waste Type: MLLW

This waste-stream is no tonger generated.

General Comments:

RCRA CODES

Waste Charcterization Basis: Sampling Analysis

\begin{tabular}{|l|l|l|}
\hline Waste Codes & LDR Basis & Best Demonstrated Available Technologies \\
\hline D007 & Conc. & $\begin{array}{l}\text { Chemical Reduction followed by stabilizatio } \\
n\end{array}$ \\
\hline
\end{tabular}


State: Missouri

Site: WELDON SPRING SITE

Waste stream Name: OILS/SOLVENTS WITH LEAD

Matrix: Organic Liquids
ID \# :

2250

Waste Type: MLLW

Waste Stream Description and Source:

6 55-gallon drums containing a variety of lead-contaminated liquids including oils and solvents. Generated through consolidated and containerization in DOT drums of chemicals abandoned at the former uranium processing plant. Measured concentrations of uranium and thorium are 1.9-114 pCi/g and $<0.3-2.1 \mathrm{pCi} / \mathrm{g}$, respectively.

\begin{tabular}{|c|c|c|c|c|c|c|c|}
\hline \multicolumn{6}{|c|}{$\begin{array}{l}\text { Current Inventory as } \\
\text { of December } 31,1992\end{array}$} & \multirow{2}{*}{\multicolumn{2}{|c|}{$\begin{array}{l}\text { PROJECTED } \\
\text { GENERATION } \\
1993 \text { THROUGH } \\
199.7\end{array}$}} \\
\hline \multicolumn{2}{|c|}{$\begin{array}{l}\text { Not Subject To } \\
\text { LDR Prohibition }\end{array}$} & \multicolumn{2}{|c|}{$\begin{array}{l}\text { SUBJECT TO } \\
\text { LDR Prohibition }\end{array}$} & \multicolumn{2}{|c|}{ TOTAL } & & \\
\hline $\begin{array}{l}\text { Cubic } \\
\text { Meter }\end{array}$ & $\mathrm{kg}$ & $\begin{array}{l}\text { Cubic } \\
\text { Meter }\end{array}$ & $\mathrm{kg}$ & $\begin{array}{l}\text { Cubic } \\
\text { Meter }\end{array}$ & $\mathrm{kg}$ & $\begin{array}{l}\text { Cubic } \\
\text { Meter }\end{array}$ & $\mathrm{kg}$ \\
\hline 0.000 & 0.000 & 1.300 & 856.0 & 1.300 & 856.0 & 0.000 & 0.000 \\
\hline
\end{tabular}

Treatability Group:

MLLW $\mathrm{CH}$, Organic Liquids, Toxic Metals w/o Mercury

Treatment status:

Have not identified a planned facility for this waste stream at this time.

Technology Status:

Technology exists. Needs modifications or verification for application to DOE waste streams.

Radiation Characteristics:

1) Contact-handled

2) Alpha emitter, < $10 \mathrm{nCi} / \mathrm{g}$

Waste Specific Radiation Effects on Treatment:

1) None.

Waste Minimization Activitiies:

Waste is no longer being generated.

General Comments: 
2

State: Missouri

Site: WELDON SPRING SITE

ID \# :

2250

Waste Stream Name: OILS/SOLVENTS WITH LEAD

Matrix: Organic Liquids

Waste Type: MLLW

RCRA CODES

Waste Charcterization Basis: Sampling Analysis

\begin{tabular}{|l|l|l|}
\hline Waste Codes & LDR Basis & Best Demonstrated Available Technologies \\
\hline D001A & Tech. & $\begin{array}{l}\text { Fuel Substitution; Organics Recovery; or I } \\
\text { ncineration }\end{array}$ \\
\hline D008B & Conc. & Stabilization \\
\hline
\end{tabular}

$05 / 17 / 94$ 
State: Missouri

ID \# :

Site: WELDON SPRING SITE

Waste Stream Name: ORGANIC LIQUIDS WITH LEAD (D008-LIQUIDS)

Matrix: Organic Liquids Waste Type: MLLW

Waste Stream Description and Source:

5 drums (4 55-gallon and 1 85-gallon) containing a variety of lead-contaminated bulk free liquids, including oils. Generated through consolidation and containerization in DOT drums of chemicals abandoned at the former uranium processing plant. Thorium 228, thorium 230, and thorium 232 at $<1-3 \mathrm{pCi} / \mathrm{g}$. Uranium at $<1-20,400 \mathrm{pCi} / \mathrm{L}$.

\begin{tabular}{|c|c|c|c|c|c|c|c|}
\hline \multicolumn{6}{|c|}{$\begin{array}{l}\text { Current Inventory as } \\
\text { of December } 31,1992\end{array}$} & \multirow{2}{*}{\multicolumn{2}{|c|}{$\begin{array}{l}\text { PROJECTED } \\
\text { GENERATION } \\
1993 \text { THROUGH } \\
1997\end{array}$}} \\
\hline \multicolumn{2}{|c|}{$\begin{array}{l}\text { Not Subject To } \\
\text { LDR Prohibition }\end{array}$} & \multicolumn{2}{|c|}{$\begin{array}{l}\text { SUBJECT TO } \\
\text { LDR Prohibition }\end{array}$} & \multicolumn{2}{|c|}{ TOTAL } & & \\
\hline $\begin{array}{l}\text { Cubic } \\
\text { Meter }\end{array}$ & $\mathrm{kg}$ & $\begin{array}{l}\text { Cubic } \\
\text { Meter }\end{array}$ & $\mathrm{kg}$ & $\begin{array}{l}\text { Cubic } \\
\text { Meter }\end{array}$ & $\mathrm{kg}$ & $\begin{array}{l}\text { Cubic } \\
\text { Meter }\end{array}$ & $\mathrm{kg}$ \\
\hline 0.000 & 0.000 & 1.200 & 765.0 & 1.200 & 765.0 & 0.000 & 0.000 \\
\hline
\end{tabular}

Treatability Group:

MLLW $\mathrm{CH}$, Organic Liquids, Toxic Metals w/o Mercury

Treatment status:

Have not identified a planned facility for this waste stream at this time.

Technology status:

Technology exists. Needs modifications or verification for application to DOE waste streams.

Radiation Characteristics:

1) Contact-handled

2) Alpha emitter, < $10 \mathrm{nci} / \mathrm{g}$

Waste Specific Radiation Effects on Treatment:

1) None.

Waste Minimization Activitiies:

Waste is no longer being generated.

General Comments: 
State: Missouri

ID \# :

471

Site: WELDON SPRING SITE

Waste stream Name: ORGANIC LIQUIDS WITH LEAD (D008-LIQUIDS)

Matrix: Organic Liquids

Waste Type:

MLLW

RCRA CODES

Waste Charcterization Basis: Sampling Analysis

\begin{tabular}{|l|l|l|}
\hline Waste Codes & LDR Basis & Best Demonstrated Available Technologies \\
\hline D008B & Conc. & Stabilization \\
\hline
\end{tabular}


State: Missouri

Site: WELDON SPRING SITE

ID \# :

2246

Waste Stream Name: ETHYLENE GLYCOL WITH TETRACHLOROETHYLENE

Matrix: Organic Liquids

Waste Type: MLLW

Waste Stream Description and Source:

30 55-gallon drums of ethylene glycol contaminated with tetrachloroethylene. Generated through consolidation and containerization in DOT drums of chemicals abandoned at the former uranium processing plant. Measured concentrations of uranium and thorium are 3-9 $\mathrm{pCi} / \mathrm{L}$ and $<0.1-1.5 \mathrm{pCi} / \mathrm{L}$, respectively.

\begin{tabular}{|c|c|c|c|c|c|c|c|}
\hline \multicolumn{6}{|c|}{$\begin{array}{l}\text { Current Inventory as } \\
\text { of December } 31,1992\end{array}$} & \multirow{2}{*}{\multicolumn{2}{|c|}{$\begin{array}{l}\text { PROJECTED } \\
\text { GENERATION } \\
1993 \text { THROUGH } \\
1997\end{array}$}} \\
\hline \multicolumn{2}{|c|}{$\begin{array}{l}\text { Not Subject To } \\
\text { LDR Prohibition }\end{array}$} & \multicolumn{2}{|c|}{$\begin{array}{l}\text { SUBJECT TO } \\
\text { LDR Prohibition }\end{array}$} & \multicolumn{2}{|c|}{ TOTAL } & & \\
\hline $\begin{array}{l}\text { Cubic } \\
\text { Meter }\end{array}$ & $\mathrm{kg}$ & $\begin{array}{l}\text { Cubic } \\
\text { Meter }\end{array}$ & $\mathrm{kg}$ & $\begin{array}{l}\text { Cubic } \\
\text { Meter }\end{array}$ & $\mathrm{kg}$ & $\begin{array}{l}\text { Cubic } \\
\text { Meter }\end{array}$ & $\mathrm{kg}$ \\
\hline 6.200 & $6.489 E \quad 3$ & 0.000 & 0.000 & 6.200 & $6.489 \mathrm{E} 3$ & 0.000 & 0.000 \\
\hline
\end{tabular}

Treatability Group:

MLLW CH, Organic Liquids, Toxic Organics

Treatment Status:

Have not identified a planned facility for this waste stream at this time.

Technology Status:

Technology exists. Needs modifications or verification for application to DOE waste streams.

Radiation Characteristics:

1) Contact-handled

2) Alpha emitter, < $10 \mathrm{nCi} / \mathrm{g}$

Waste Specific Radiation Effects on Treatment:

1) None.

Waste Minimization Activitiies:

Waste is no longer being generated.

General Comments: 
State: Missouri

ID \# :

2246

Site: WELDON SPRING SITE

Waste Stream Name: ETHYLENE GLYCOL WITH TETRACHLOROETHYLENE

Matrix: Organic Liquids

Waste Type: MLLW

RCRA CODES

Waste Charcterization Basis: Sampling Analysis

\begin{tabular}{|l|l|l|}
\hline Waste Codes & LDR Basis & Best Demonstrated Available Technologies \\
\hline D039 & & $\begin{array}{l}\text { Not currently prohibited under the LDR Prog } \\
\text { ram. }\end{array}$ \\
\hline
\end{tabular}


State: New Mexico

ID \#: 0000002055

Site: LOS ALAMOS NATIONAL LABORATORY

Waste stream Name: IGNITABLE LIQUIDS

Matrix: Organic Liquids

Waste Type: MLLW

Waste Stream Description and Source:

principally comprised of used scintillation cocktails containing trimethylbenzene (pseudodocumene). Used in scintillation counting in detection or monitoring.

\begin{tabular}{|c|c|c|c|c|c|c|c|}
\hline & & $\begin{array}{l}\text { urrent } \\
\text { f Dece }\end{array}$ & $\begin{array}{l}\text { ventory } \\
r 31,1\end{array}$ & & & \multirow{2}{*}{\multicolumn{2}{|c|}{$\begin{array}{l}\text { PROJECTED } \\
\text { GENERATION } \\
1993 \text { THROUGH } \\
1997\end{array}$}} \\
\hline \multicolumn{2}{|c|}{$\begin{array}{l}\text { Not Subject To } \\
\text { LDR Prohibition }\end{array}$} & \multicolumn{2}{|c|}{$\begin{array}{l}\text { SUBJECT TO } \\
\text { LDR Prohibition }\end{array}$} & \multicolumn{2}{|c|}{ TOTAL } & & \\
\hline $\begin{array}{l}\text { Cubic } \\
\text { Meter }\end{array}$ & $\mathrm{kg}$ & $\begin{array}{l}\text { Cubic } \\
\text { Meter }\end{array}$ & $\mathrm{kg}$ & $\begin{array}{l}\text { Cubic } \\
\text { Meter }\end{array}$ & $\mathrm{kg}$ & $\begin{array}{l}\text { Cubic } \\
\text { Meter }\end{array}$ & $\mathrm{kg}$ \\
\hline 79.40 & - & 0.000 & - & 79.40 & - & 87.70 & - \\
\hline
\end{tabular}

Treatability Group:

MLLW $\mathrm{CH}$, Organic Liquids, Ignitable, Corrosive, or Reactive only

Treatment status:

Plan to treat on-site at the existing scintillation vial cru sher facility.

Onsite incineration at controlled air incinerator pending

DOE NEPA; DETOX at hazardous waste treatment facility;

offsite capabilities.

Technology status:

Technology exists. No modifications are necessary.

Radiation Characteristics:

1) Radionuclides or radiation level unknown

2) Contact-handled

Waste Specific Radiation Effects on Treatment:

Waste Minimization Activitiies:

1) Raw material changes: raw material purification; and su bstitution.

General Comments:

$05 / 17 / 94$ 
State: New Mexico

Site: LOS ALAMOS NATIONAL LABORATORY

Waste stream Name: IGNITABLE LIQUIDS

Matrix: Organic Liquids
ID \# : 0000002055

Waste Type: MLLW

RCRA CODES

Waste Charcterization Basis: Process Knowledge

\begin{tabular}{|l|l|l|}
\hline Waste Codes & LDR Basis & Best Demonstrated Available Technologies \\
\hline D001A & Tech. & $\begin{array}{l}\text { Fuel Substitution; Organics Recovery; or I } \\
\text { ncineration }\end{array}$ \\
\hline
\end{tabular}


State: New Mexico

ID \# : 0000002180

Site: LOS ALAMOS NATIONAL LABORATORY

Waste Stream Name: SPENT SOLVENTS - F003

Matrix: Organic Liquids

Waste Type: MLLW

Waste Stream Description and Source:

Waste stream includes acetone, methanol, xylene.

\begin{tabular}{|c|c|c|c|c|c|c|c|}
\hline \multicolumn{6}{|c|}{$\begin{array}{l}\text { Current Inventory as } \\
\text { of December } 31,1992\end{array}$} & \multirow{2}{*}{\multicolumn{2}{|c|}{$\begin{array}{l}\text { PROJECTED } \\
\text { GENERATION } \\
1993 \text { THROUGH } \\
1997\end{array}$}} \\
\hline \multicolumn{2}{|c|}{$\begin{array}{l}\text { Not Subject To } \\
\text { LDR Prohibition }\end{array}$} & \multicolumn{2}{|c|}{$\begin{array}{l}\text { SUBJECT TO } \\
\text { LDR Prohibition }\end{array}$} & \multicolumn{2}{|c|}{ TOTAL } & & \\
\hline $\begin{array}{l}\text { Cubic } \\
\text { Meter }\end{array}$ & $\mathrm{kg}$ & $\begin{array}{l}\text { Cubic } \\
\text { Meter }\end{array}$ & $\mathrm{kg}$ & $\begin{array}{l}\text { Cubic } \\
\text { Meter }\end{array}$ & $\mathrm{kg}$ & $\begin{array}{l}\text { Cubic } \\
\text { Meter }\end{array}$ & $\mathrm{kg}$ \\
\hline 8.400 & - & 7.700 & - & 16.20 & - & 21.10 & - \\
\hline
\end{tabular}

Treatability Group:

MLLW $\mathrm{CH}$, Organic Liquids, Toxic Organics

Treatment status:

Plan to treat on-site at the existing controlled Air Inciner ator facility.

Treatment at the Controlled Air Incinerator pending DOE

NEPA; DETOX at the Hazardous waste Treatment Facility is pending issuance of a RCRA operating permit.

Technology status:

Technology exists. No modifications are necessary.

Radiation Characteristics:

1) Radionuclides or radiation level unknown

2) Contact-handled

Waste Specific Radiation Effects on Treatment:

Waste Minimization Activitiies:

1) Technology changes: process changes; equipment, piping , or layout changes; automation; changes in operation al settings; and energy, water conservation.

General Comments:

RCRA CODES 
State: New Mexico

Site: LOS ALAMOS NATIONAL LABORATORY

Waste Stream Name: SPENT SOLVENTS - F003

Matrix: Organic Liquids
ID \# : 0000002180

Waste Type: MLLW

Waste Charcterization Basis: Process Knowledge

\begin{tabular}{|l|l|l|}
\hline Waste Codes & LDR Basis & Best Demonstrated Available Technologies \\
\hline F003 & Conc. & Incineration \\
\hline
\end{tabular}


State: New Mexico

ID \# : 0000002176

Site: LOS ALAMOS NATIONAL LABORATORY

Waste Stream Name: SPENT SOLVENTS - FO02

Matrix: Organic Liquids

Waste Type: MLLW

Waste Stream Description and Source:

Waste stream includes 1,1,1-trichloroethane and trichlorethylene.

\begin{tabular}{|c|c|c|c|c|c|c|c|}
\hline \multicolumn{6}{|c|}{$\begin{array}{l}\text { Current Inventory as } \\
\text { of December } 31,1992\end{array}$} & \multirow{2}{*}{\multicolumn{2}{|c|}{$\begin{array}{l}\text { PROJECTED } \\
\text { GENERATION } \\
1993 \text { THROUGH } \\
1997\end{array}$}} \\
\hline \multicolumn{2}{|c|}{$\begin{array}{l}\text { Not Subject To } \\
\text { LDR Prohibition }\end{array}$} & \multicolumn{2}{|c|}{$\begin{array}{l}\text { SUBJECT TO } \\
\text { LDR Prohibition }\end{array}$} & \multicolumn{2}{|c|}{ TOTAL } & & \\
\hline $\begin{array}{l}\text { Cubic } \\
\text { Meter }\end{array}$ & $\mathrm{kg}$ & $\begin{array}{l}\text { Cubic } \\
\text { Meter }\end{array}$ & $\mathrm{kg}$ & $\begin{array}{l}\text { Cubic } \\
\text { Meter }\end{array}$ & $\mathrm{kg}$ & $\begin{array}{l}\text { Cubic } \\
\text { Meter }\end{array}$ & $\mathrm{kg}$ \\
\hline 8.200 & - & 4.500 & - & 12.70 & - & 18.50 & - \\
\hline
\end{tabular}

Treatability Group:

MLLW $\mathrm{CH}$, Organic Liquids, Toxic Organics

Treatment status:

Plan to treat on-site at the existing Controlled Air Inciner ator facility.

Treatment at the Controlled Air Incinerator pending DOE NEPA; DETOX at the Hazardous Waste Treatment Facility is pending issuance of a RCRA operating permit.

Technology status:

Technology exists. No modifications are necessary.

Radiation Characteristics:

1) Radionuclides or radiation level unknown

2) Contact-handled

Waste Specific Radiation Effects on Treatment:

Waste Minimization Activitiies:

1) Improved operating practices: changes in material handl ing and inventory procedures; waste segregation; and changes in production scheduling.

2) Technology changes: process changes; equipment, piping , or layout changes; automation; changes in operation al settings; and energy, water conservation.

3) Product change: product substitution and conservation; 
State: New Mexico

ID \#: 0000002176

Site: LOS ALAMOS NATIONAL LABORATORY

Waste Stream Name: SPENT SOLVENTS - F002

Matrix: Organic Liquids

Waste Type: MLLW

and change in product composition.

General Comments:

RCRA CODES

Waste Charcterization Basis: Process Knowledge

\begin{tabular}{|l|l|l|}
\hline Waste Codes & LDR Basis & Best Demonstrated Available Technologies \\
\hline F002 & Conc. & Incineration \\
\hline
\end{tabular}


State: New Mexico

ID \#: 0000002184

Site: LOS ALAMOS NATIONAL LABORATORY

Waste stream Name: SPENT SOLVENTS - F005

Matrix: Organic Liquids

Waste Type: MLLW

waste Stream Description and Source:

Waste stream includes benzene, pyridine, toluene.

\begin{tabular}{|c|c|c|c|c|c|c|c|}
\hline \multicolumn{6}{|c|}{$\begin{array}{l}\text { Current Inventory as } \\
\text { of December } 31,1992\end{array}$} & \multirow{2}{*}{\multicolumn{2}{|c|}{$\begin{array}{l}\text { PROJECTED } \\
\text { GENERATION } \\
1993 \text { THROUGH } \\
1997\end{array}$}} \\
\hline \multicolumn{2}{|c|}{$\begin{array}{l}\text { Not Subject To } \\
\text { LDR Prohibition }\end{array}$} & \multicolumn{2}{|c|}{$\begin{array}{l}\text { SUBJECT TO } \\
\text { LDR Prohibition }\end{array}$} & \multicolumn{2}{|c|}{ TOTAL } & & \\
\hline $\begin{array}{l}\text { Cubic } \\
\text { Meter }\end{array}$ & $\mathrm{kg}$ & $\begin{array}{l}\text { Cubic } \\
\text { Meter }\end{array}$ & $\mathrm{kg}$ & $\begin{array}{l}\text { Cubic } \\
\text { Meter }\end{array}$ & $\mathrm{kg}$ & $\begin{array}{l}\text { Cubic } \\
\text { Meter }\end{array}$ & $\mathrm{kg}$ \\
\hline 1.400 & - & 9.400 & - & 10.80 & - & 15.70 & - \\
\hline
\end{tabular}

Treatability Group:

MLLW $\mathrm{CH}$, Organic Liquids, Toxic Organics

Treatment status:

Plan to treat on-site at the existing Controlled Air Inciner ator facility.

Treatment at the Controlled Air Incinerator pending DOE

NEPA; DETOX at the Hazardous Waste Treatment Facility is pending issuance of a RCRA operating permit.

Technology status:

Technology exists. No modifications are necessary.

Radiation Characteristics:

1) Radionuclides or radiation level unknown

2) Contact-handled

Waste Specific Radiation Effects on Treatment:

Waste Minimization Activitiies:

1) Product change: product substitution and conservation; and change in product composition.

General Comments:

RCRA CODES 
State: New Mexico

Site: LOS ALAMOS NATIONAL LABORATORY

Waste Stream Name: SPENT SOLVENTS - F005

Matrix: Organic Liquids
ID \#: 0000002184

Waste Type: MLLW

Waste Charcterization Basis: Process Knowledge

\begin{tabular}{|l|l|l|}
\hline Waste Codes & LDR Basis & Best Demonstrated Available Technologies \\
\hline F005A & Conc. & Incineration \\
\hline
\end{tabular}


Attachment 8

$-121-$ 
$-122-$ 


\section{Delphi Research, Inc. \\ Risk Management Policy for \\ Waste Treatment Technology Development}

The Delphi Research policy on managing risks in our waste treatment technology development programs is best summarized in two statements:

1. Nobody is more interested in the commercial success of our waste treatment technologies than we are.

2. Delphi Research is the expert on the patented chemical oxidation processes which are used in the waste treatment systems.

Primary tenets of the Delphi risk management policy are concern for safety and commercialization of our patented waste treatment technologies.

\section{SAFETY CONSIDERATIONS}

Background. The catalyzed wet oxidation process used in Delphi Research waste treatment technologies is highly corrosive and complex. It is safe and effective in treating a wide variety of mixed and hazardous wastes. It is essential that system operators and equipment be of the highest quality -well trained and motivated operators, and equipment and chemical processes controlled by well-defined procedures and control systems. Operating these systems in a hot mode to treat mixed and hazardous wastes further challenges the operators and system equipment.

Safety-personnel safety, system safety, and environmental safety-is the overriding consideration in risk management. Therefore:

A. No Delphi Research, Inc. technology will be licensed or otherwise released from company control until it is proven and qualified for the intended application. Delphi Research, Inc. will be the final decision authority on using Delphi technology in new applications.

B. In all new technology applications Delphi Research will be involved in all aspects of system design, fabrication, testing, and initial operations.

C. Delphi Research will be involved in operator training and certification at each new operating location or will approve the training personnel and curriculum when training is to be provided by another agency.

Summary. A safety incident or accident would be hard to overcome in any phase of technology development, but is a certain "show-stopper" in our current stage of development. 


\section{BUSINESS DEVELOPMENT AND COMMERCIALIZATION}

Rationale. The basis for Delphi Research, Inc.'s future as a profitable small business is the commercial success of our patented waste treatment technologies. No other company, agency, or individual has as much at stake. Having a lot at risk provides very strong motivation for success. Delphi Research being actively involved in every phase of technology development and application affords many benefits and establishes a foundation for business growth.

Delphi has many lessons learned, based on our experiences, which should be applied to every program phase. We also need to gain the experience in working with DOE, DOD, and other federal and state agencies which will further enhance our ability to manage the technology. Regulatory/compliance issues and site interface and operations requirements must be factored into many facets of each program, especially affecting operator training requirements.

A consulting or advisory role for Delphi is not acceptable and does not enhance our ability to successfully commercialize our waste treatment technologies. We cannot risk exposing our technology which we have worked hard to develop and patent to every contractor or agency who may want to investigate the technology for unjustifiable reasons.

Responsiveness to engineering changes, modifications to operating procedures, and customer requirements to evaluate new applications is best accommodated through complete participation. Delphi Research, Inc. will insist on full participation in all future contractual agreements and seek to gain full participation where limited involvement is part of current business arrangements.

Summary. Without a life-cycle technology manager the waste treatment systems would lack configuration control, logistics support, and other professional management functions which are required for safe and effective operations. Delphi Research, Inc. is the only candidate for this job. Our risk management position should be honored if our technologies are to reach the field in a timely, costeffective manner. 
Appendix B

\section{$-125-$}


$-126-$ 


\section{STATEMENT OF WORK ENGINEERING DESIGN AND FABRICATION FOR A DETOXSM WET OXIDATION WASTE TREATMENT UNIT}

\section{$\underline{1.0}$ SCOPE}

1.1 The scope of this contract involves three stages: (1) an engineering design, (2) a prototype manufacturing engineering and fabrication phase, and (3) field testing and demonstration support. The engineering design (Stage 1) effort is for a generic waste treatment unit which shall process a wide variety of hazardous and mixed wastes and shall be transportable for use at various DOE sites. The manufacturing engineering and fabrication (Stage 2) will be a priced contract option. Field testing and demonstration (Stage 3) will be an unpriced contract option. Field testing and demonstration is planned for two DOE sites, which will be identified in Stage 1 .

1.2 Objective. The objective of this acquisition is to meet the requirements of the Delphi Research, Inc. contract with DOE Morgantown, West Virginia, contract number DE-AC21-92MC27109, to develop a waste treatment unit for processing and disposing of hazardous, multicomponent, mixed wastes.

1.3 Background. The Delphi Research DETOXSM process uses a unique catalyzed wet oxidation technique to destroy organic compounds while containing and concentrating many metals. The process utilizes a patented combination of homogeneous metal catalysts in an acidic water solution. Organic compounds placed in the solution are oxidized 
with high efficiency. Many toxic metals are dissolved and concentrated in the solution and can be recovered through various means depending on the nature of the chemical reactions. The DETOXSM process is distinguished from other types of wet oxidation by its high organics destruction efficiencies at relatively low temperature and pressure. The process is highly tolerant of waste composition, form, water content, and particle size. Because DETOXSM is a low temperature process which can be operated as a closed or confined system, there is much less concern with the possible escape of toxic materials in exhaust gases.

\subsection{APPLICABLE GUIDANCE AND DOCUMENTS}

2.1 Compliance Documents. Part II, Section I, Attachments A and B contain the most current and comprehensive listing of appropriate FARs and DEARs. For the purpose of this anticipated subcontract, anywhere a FAR or DEAR has 'Government,' substitute Delphi Research, Inc. Also, Delphi Research shall perform all appropriate subcontract administration and management functions excluding audit tasks and examination of costs and pricing data.

2.1.1 Codes, Standards, and Regulations. The contractor shall specify and comply with all design, construction, quality, and safety codes, standards, and regulations. 


\subsection{WORK DESCRIPTION}

3.1 Stage 1-Engineering Design. The contractor shall develop design requirements and produce a detailed engineering design for a transportable prototype waste treatment unit based on the preliminary Weldon Spring design with enhanced design features. In addition to the liquid waste feed design requirement, the contractor shall provide for a solids feed capability to accommodate solids with particle size of no greater than $1 / 2$ inch. Other new design requirements are a tantalum reflux condenser (equivalent to 10. plates) for processing reactor unit off-gases and an oxygen sparge system to treat condensate prior to returning to the reactor vessel. The design shall include necessary drawings, specifications, and information sufficient to compete fabrication and assembly.

3.1.1 Engineering design shall address modular configuration and transportability options.

3.1.2 Other areas and issues to be addressed in engineering design are: environmental monitoring, instrumentation and controls, communications and alarms, auxiliary/emergency power, fire protection, ventilation, process utilities, containment, operations, and maintenance.

3.1.3 The contractor shall provide an updated fabrication cost and cost of long lead items twelve (12) weeks after contract award. These data may be used by DOE-METC to authorize long lead purchase 
to reduce program schedule risks. Also, the contract shall provide a Stage 2 fabrication cost estimate at the end of the engineering design phase.

\subsection{Stage 2-Manufacturing Engineering and Fabrication}

3.2.1 Fabrication Requirements. The task to fabricate waste treatment unit will be a priced option. Upon award of the Stage 2 fabrication option, the contractor shall procure all parts, materials, and equipment and assemble the prototype unit. The unit shall be constructed and assembled for ease of transportation.

3.2.2 As part of the Stage 2 effort the contractor shall prepare operating documentation to include: operating manuals, maintenance manuals, acceptance plans, and functionality test plans.

3.2.3 The contractor shall provide on-site support for initial delivery and acceptance tests of the unit at Delphi Research, Inc. in Albuquerque, New Mexico. The period for this support is "as required."

3.2.4 Training Support. Upon delivery of the unit to Delphi in Albuquerque, the contractor shall provide training and orientation to Delphi personnel as part of the acceptance test requirements. Assume three (3) Delphi personnel for this level of training and system familiarization. The contractor shall propose the time and other resources required for this training. 


\subsection{Stage 3-Field Testing and Demonstration Support.}

3.3.1 The prototype unit will be field tested and used to demonstrate waste treatment effectiveness and suitability at two DOE sites. These sites will be determined during the engineering design stage.

3.3.2 Field site activities are planned for seven (7) months at each location with two (2) months between sites for prototype unit inspection, repair, and modification. The seven months on-site period includes: (a) one (1) month for packing, transportation, set-up, calibration, and functionality tests; (b) two (2) months for surrogate material testing based on the site-specific waste stream characteristics and; (c) four (4) months for hazardous and mixed waste treatment.

3.3.3 The contractor shall support end of contract analysis, reporting, and commercialization assessment for the DETOXSM waste treatment technology. Tasking included in this paragraph is anticipated to last two (2) months.

3.4 Program Management. The contractor shall accomplish routine management. These management tasks shall include administrative, management, and secretarial functions required to perform the engineering design and fabrication and assembly activities. The contractor shall be responsible for managing and maintaining control of all contractor efforts, including any subcontractors or consultants, to maintain timely, cost-effective performance. The contractor shall 
formulate, plan and use an effective control system for cost, schedule, and technical efforts to insure satisfactory accomplishment of contract and program objectives and to provide prompt, clear visibility to Delphi Research, Inc. in all aspects of this effort.

3.4.1 Management Plan. The contractor shall develop and, when approved by Delphi, implement a Management Plan which details the contractor's approach for accomplishing all required contract actions. The contractor shall update the Management Plan to incorporate new or revised contract requirements.

3.4.2 Program Manager. The contractor shall provide for a single point-of-contact with the authority to make and execute programmatic and administrative decisions. The contractor shall provide the management skills necessary to efficiently plan, schedule, implement, direct, and document the technical design and fabrication efforts specified in this SOW.

3.4.3 Management Reviews. The contractor shall hold periodic design and fabrications reviews to inform Delphi Research, Inc. and selected DOE personnel on the status, schedules, and plans of projected and ongoing efforts. The frequency and location of these reviews and meetings are addressed in Section 4.0, Contract Reviews and Deliverables. More frequent meetings may be initiated by the contractor, Delphi Research, or DOE Morgantown to discuss technical, administrative, and management concerns. These meetings will be informal with 
briefing/discussion material provided in the contractor's selected format. The contractor shall also host formal design and fabrication reviews as specified in section 4.0.

\subsection{CONTRACT REVIEWS AND DELIVERABLES}

4.1 Reviews. The contractor shall plan and host three (3) formal reviews in Stage 1 and three (3) formal reviews in Stage 2.

\subsubsection{Stage 1-Engineering Design Reviews:}

a. Preliminary Design Review - 60-75 days after contract award. Purpose: To provide scope and design focus confirmation based on site survey data and an opportunity for DOE to address any changes in objectives or program priorities.

b. Critical Design Review - no fixed date required; near end of design efforts but in time to accommodate small-to-medium design changes.

Purpose: To address design changes based on new data which is in scope of defined tasking.

c. Design Completion Fabrication Cost Review - at or near the end of design phase.

Purpose: To show evidence that design work is complete and all changes have been incorporated (draft final complete 
documentation is required). Presenting the revised fabrication cost proposal is equally important at this review.

4.1.2 Stage 2-Manufacturing Engineering, and Fabrication Reviews:

a. Functional Configuration Audit or Review - to be held after all vendor data are available and incorporated in the system design documentation. Paper review is the anticipated format.

Purpose: To permit DOE to review the list of vendors, vendor-supplied material specifications, and to confirm system, subsystem, and component functional requirements.

b. Physical Configuration Review - near completion of unit assembly.

Purpose: To demonstrate assembly and fabrication progress and validate final system configuration and preview operation and maintenance manuals.

c. Final Configuration Review - after full assembly and initial contractor integration testing.

Purpose: To demonstrate unit with a functionality test and verify final system configuration and review draft system manuals to include: (1) operations manual(s); (2) maintenance manual(s); (3) functionality test plan, and; (4) acceptance test plan. 
4.2 Deliverables. The contractor shall provide a draft Management Plan to Delphi Research, Inc. for review and approval thirty (30) days after contract award. Delphi Research, Inc. will review the Management Plan and provide comments or approval within fifteen (15) days of receiving the draft plan. All subsequent updates, if required, shall be on a fifteen (15) day turnaround cycle. Management Plan updates are required on the above schedule for Stage 2 and Stage 3. Materials and supporting information shall be provided to Delphi Research, Inc. at least ten (10) days prior to all formal reviews. Ten (10) copies of this information is required. DRI will distributed this information to DOE participants.

\subsubsection{Stage 1-Engineering Design Deliverables. Other than the} deliverables to support the formal reviews described above, the contractor shall provide:

a. Monthly Reports which highlight monthly progress, costs, problem areas with recommended solutions, and a forecast of activities for the next month.

b. Final Engineering Design - Ten (10) complete sets of the engineering design package are required within thirty (30) days after Design Completion Review.

c. Stage 2-Manufacturing Engineering and Fabrication Cost Proposal - Five (5) copies of this cost proposal are required ten (10) days after Design Completion Review. 


\subsubsection{Stage 2-Manufacturing Engineering and Fabrication Deliverables.}

a. Monthly Reports-see paragraph 4.2.1.a above.

b. As-built Engineering Data Package. Includes all documents and plans listed in paragraph 4.1.2.c. This package shall incorporate all changes in the prototype unit including those made at the Final Configuration Review. Ten (10) complete sets are required within thirty (30) days after Final Configuration Review.

c. Prototype waste treatment unit hardware. This prototype unit shall be delivered to Delphi Research, Inc. in Albuquerque, NM within thirty (30) days after Final Configuration Review.

NOTE: Stage 3, Field Testing and Demonstration Support reviews and deliverables will be determined later. 
Appendix C 
$-138-$ 


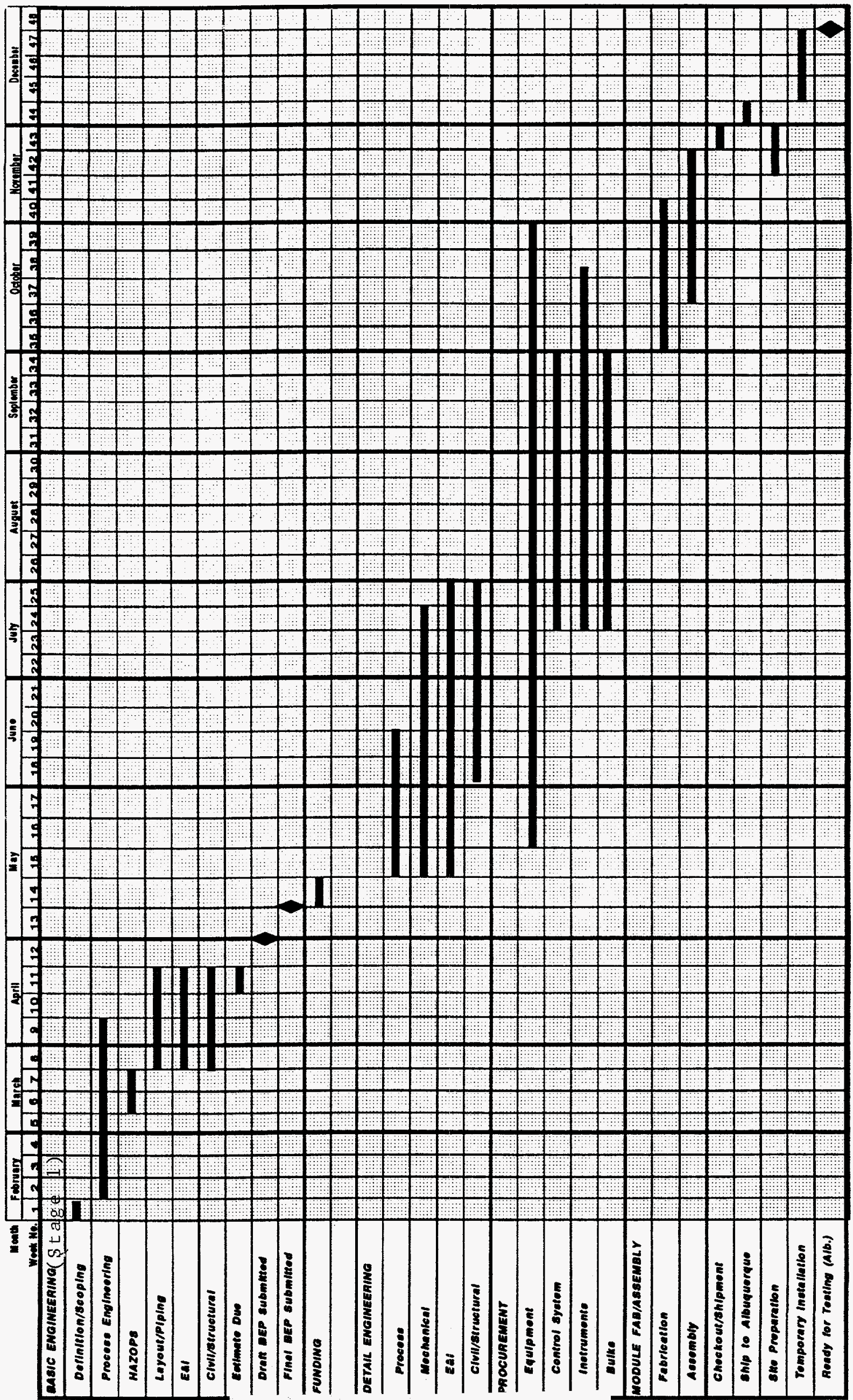


$-140-$ 